Carlos Eduardo Santa Ritta Barreira

\title{
Análise da ultra-estrutura do tecido paratireóideo humano em solução para preservação de tecidos
}

Tese apresentada à Faculdade de Medicina da Universidade de São Paulo para obtenção do título de Doutor em Ciências

Área de Concentração: Clínica Cirúrgica Orientador: Prof. Dr. Cláudio Roberto Cernea

São Paulo

2010 
Dados Internacionais de Catalogação na Publicação (CIP) Preparada pela Biblioteca da

Faculdade de Medicina da Universidade de São Paulo

Creprodução autorizada pelo autor

Barreira, Carlos Eduardo Santa Ritta

Análise da ultra-estrutura do tecido paratireóideo humano em solução para preservação de tecidos / Carlos Eduardo Santa Ritta Barreira. -- São Paulo, 2010.

Tese(doutorado)--Faculdade de Medicina da Universidade de São Paulo.

Departamento de Clínica Cirúrgica.

Área de concentração: Cirurgia.

Orientador: Cláudio Roberto Cernea.

Descritores: 1.Criopreservação 2.Glândulas paratireóides

3.Preservação de órgãos 4.Paratireoidectomia 5.Auto-implante

6.Microscopia eletrônica 7.Hiperparatireoidismo

USP/FM/SBD-033/10 
Dedico este trabalho aos meus pais, Edmilson e Isa, a minha esposa

Ranna, que tanto amo, e a meus filhos Caio e Eduardo. 


\section{Agradecimentos}

Ao Dr. Fábio Luiz de Menezes Montenegro, pela inspiração e pelos sólidos ensinamentos sobre o tema abordado. Registro inestimável admiração pelo profissional dedicado, ético, polido, criterioso e gentil. Seu profundo conhecimento, e dedicação ao ensino e a pesquisa sobre as patologias das glândulas paratireóides contagia e provoca paixão pelo tema.

A Dra. Elia Caldini, pela solicitude e orientações relacionadas à microscopia eletrônica. Seus conhecimentos foram fundamentais para o desenvolvimento desta tese.

Ao Dr. Fernando Luís Dias, pelo exemplo de profissionalismo e liderança, decisivos para minha formação profissional, e pelo interesse no desenvolvimento das atividades acadêmicas.

Aos Professores Dr. Alberto Rossetti Feraz, Dr. Lenine Garcia Brandão e Dr. Cláudio Roberto Cernea, agradeço pela oportunidade de desenvolver esta tese nesta renomada instituição.

Aos Doutores Ségio Samir Arap, Marcos Roberto Tavares, Rodrigo Oliveira Santos e Melani Custódio, agradeço pelas valiosas orientações prestadas no exame de qualificação.

Aos residentes do Serviço de Cirurgia de Cabeça e Pescoço do HCFMUSP, pela atenciosa colaboração na coleta do material deste estudo.

Aos funcionários do Centro Multiusuário de Microscopia Eletrônica da Faculdade de Medicina da Universidade de São Paulo, sempre muito atenciosos e dedicados, registro meus sinceros agradecimentos.

A Sra. Eliane Falconi Monico Gazetto, agradeço pela atenção, pelos cuidados, e pela presteza na resolução dos tramites burocráticos da pósgraduação.

Ao Dr. Cláudio Neto Estrella e aos colegas do Serviço de Cirurgia de Cabeça e Pescoço do Hospital de Base do Distrito Federal, pela paciência e compreensão pelos momentos de ausência, durante o desenvolvimento desta tese.

Aos meus sócios da Clínica CICAP, Dr. André Póvoa, Dr. Ernandes Nakamura e Dr. Marcelo Cavassani, agradeço pelo apoio aos meus pacientes em Brasília, que nunca se sentiram desassistidos na minha ausência, devido a esta forte parceria. 
Esta tese está de acordo com as seguintes normas:

Referências: adaptado de International Committee of Medical Journals Editors

(Vancouver).

Universidade de São Paulo. Faculdade de Medicina. Serviço de Biblioteca e Documentação. Guia de apresentação de dissertações, teses e monografias. Elaborado por Anneliese Carneiro da Cunha, Maria Julia de A. L. Freddi, Maria Crestana, Marinalva de Souza Aragão, Suely Campos Cardoso, Valéria Vilhena. 2a ed. São Paulo: Serviço de Biblioteca e Documentação; 2005.

Abreviaturas dos títulos dos periódicos de acordo com List of Journals Indexed in Index Medicus. 


\section{Sumário}

Lista de siglas e abreviaturas

Lista de tabelas

Lista de figuras

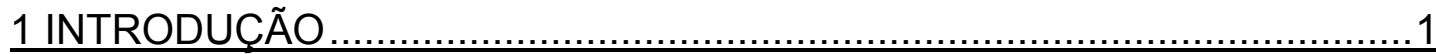

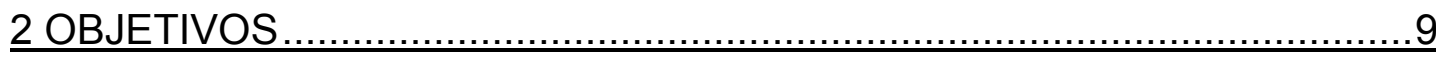

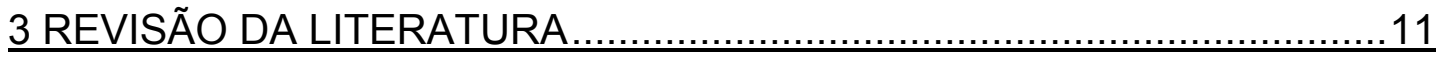

3.1 UlTRA-ESTRUTURA DO TECIDO PARATIREOIDEO HUMANO ...................... 12

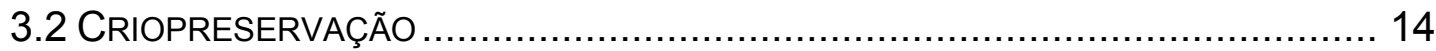

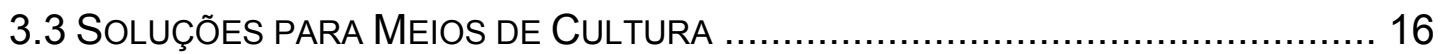

3.4 MICROSCOPIA ELETRÔNICA DE TRANSMISSÃO ........................................ 18

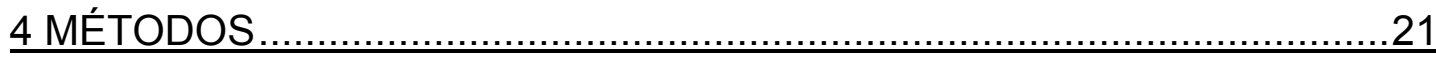

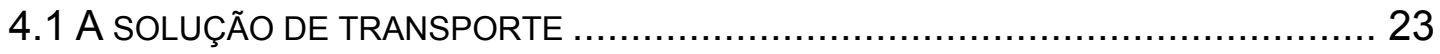

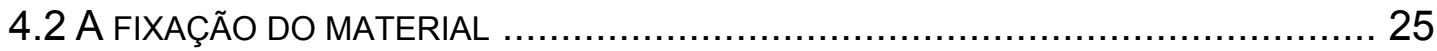

4.3 A FIXAÇÃO DO MATERIAL ACONDICIONADO EM MEIO DE TRANSPORTE............. 26

4.4 PREPARO DO MATERIAL PARA MICROSCOPIA ELETRÔNICA DE TRANSMISSÃO .. 27

4.5 ANÁLISE POR MICROSCOPIA ELETRÔNICA ......................................... 29

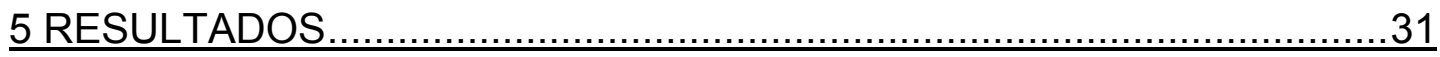

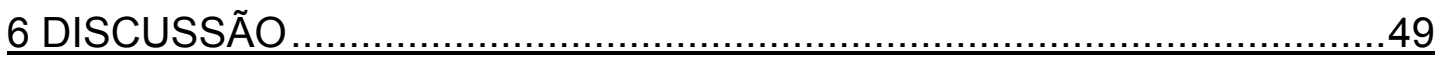

6.1 RELEVÂNCIA CLÍNICA DESTE ESTUdO ............................................... 50

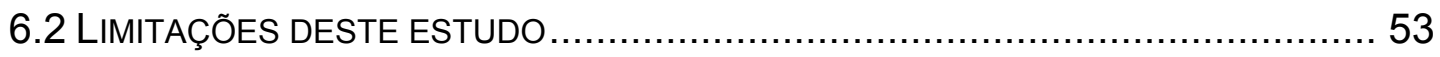

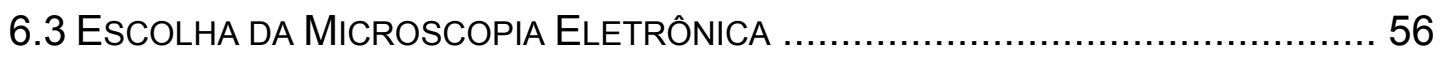

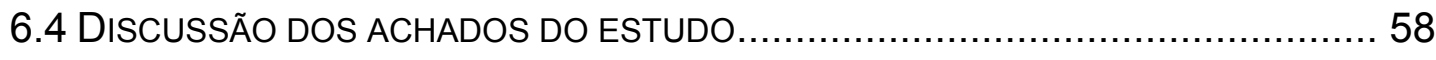

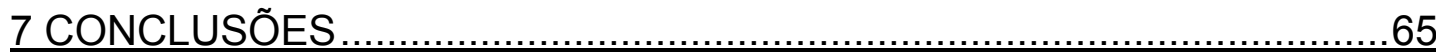

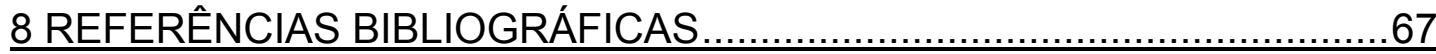




\section{Lista de siglas e abreviaturas}

\begin{tabular}{|c|c|}
\hline PTH & Paratormônio \\
\hline HPT1 & Hiperparatireoidismo primário \\
\hline HPT2 & Hiperparatireoidismo secundário \\
\hline HCFMUSP & Hospital das Clínicas da Faculdade de Medicina da \\
\hline & Universidade de São Paulo \\
\hline ME & Microscopia eletrônica \\
\hline DMSO & Dimetil-sulfóxido \\
\hline RPMI & Roswell Park Memorial Institute \\
\hline DMEM & Dulbecco`s Modified Eagle`s Medium \\
\hline CAPPesq & Comissão de Ética para Análise de Projetos de Pesquisa \\
\hline $\mathrm{CaCl} 2$ & Cloridrato de cálcio \\
\hline $\mathrm{KCl}$ & Cloreto de potássio \\
\hline MgSO4 & Sulfato de magnésio \\
\hline $\mathrm{NaCl}$ & Cloreto de sódio \\
\hline $\mathrm{NaHCO} 3$ & Bicarbonato de sódio \\
\hline $\mathrm{NaH} 2 \mathrm{PO} 4 . \mathrm{H} 2 \mathrm{O}$ & Fosfato de sódio monobásico \\
\hline $\mathrm{Fe}(\mathrm{NO}) 3.9 \mathrm{H} 2 \mathrm{O}$ & Nitrato de ferro \\
\hline DDSA & Anidrido Dodecenil Succínico \\
\hline DMP 30 & 2,4,6-tri(dimethylaminoethyl)phenol \\
\hline TUNNEL & $\begin{array}{l}\text { Terminal deoxynucleotidyl transferase biotin-dUTP nick } \\
\text { end labeling }\end{array}$ \\
\hline
\end{tabular}




\section{Lista de símbolos}

$\begin{array}{ll}\mathbf{n}^{\circ} & \text { Número } \\ \% & \text { Porcentagem } \\ { }^{\circ} \mathbf{C} & \text { Graus centigrados } \\ \mathbf{m g} & \text { Miligramas } \\ \mathbf{p g} / \mathbf{m l} & \text { Picogramas por mililitro } \\ \boldsymbol{\mu m} & \text { Micrômetro } \\ \mathbf{m m} & \text { Milímetro } \\ \mathbf{M} & \text { Mol } \\ = & \text { Igual } \\ \mathbf{m g} / \mathbf{m l} & \text { Miligramas por mililitros }\end{array}$




\section{Lista de tabelas}

Tabela 1 - Composição do meio de cultura DMEM............................. 24

Tabela 2 - Tempos de imersão do tecido em meio de transporte ............ 27

Tabela 3 - Resumo do processo de desidratação para ME .................... 28

Tabela 4 - Composição da resina ............................................ 28

Tabela 5 - Processo de coloração das telas de cobre ......................... 29

Tabela 6 - Características avaliadas pela análise ultra-estrutural ........... 30

Tabela 7 - Caracterização geral dos achados, de acordo com a integridade ou danos teciduais encontrados no tecido avaliado por ME 


\section{Lista de figuras}

Figura 1 - Fotografia de recipientes contendo a solução para transporte

Figura 2 - Micrografia eletrônica de tecido paratireoideo humano, de paciente do grupo prevalente, correspondente ao Tempo 1 (tecido fixado a fresco, sem contato com o meio de transporte). Em destaque uma célula principal com todas as organelas em excelente estado de preservação. Barra $=2 \mu \mathrm{m}$.

Figura 3 - Micrografia eletrônica de tecido paratireoideo humano, de paciente do grupo prevalente, correspondente ao Tempo 1 (tecido fixado a fresco, sem contato com o meio de transporte. As mitocôndrias apresentam cristas intactas e o retículo endoplasmático rugoso apresenta-se bem preservado, com sua luz linear e os ribossomos aderidos à sua superfície. Barra $=1 \mu \mathrm{m}$.

Figura 4 - Micrografia eletrônica de tecido paratireoideo humano, de paciente do grupo prevalente, correspondente ao Tempo 2 (tecido fixado após duas horas em meio de transporte). São visualizadas células oxifílicas, com características normais. Notam-se membranas plasmáticas integras, e com perfeita justaposição. As mitocôndrias apresentam excelente estado de preservação, assim como o núcleo em destaque. Barra $=2 \mu \mathrm{m}$.

Figura 5 - Micrografia eletrônica de tecido paratireoideo humano, de paciente do grupo prevalente, correspondente ao Tempo 2 (tecido fixado após duas horas em meio de transporte). Em destaque as mitocôndrias apresentam excelente estado de preservação, com formato normal e cristas internas bem definidas. Barra $=1 \mu \mathrm{m}$.

Figura 6 - Micrografia eletrônica de tecido paratireoideo humano, de paciente do grupo prevalente, correspondente ao Tempo 3 (tecido fixado após seis horas em meio de transporte). São visualizadas células oxifílicas, com características normais. Notam-se membranas plasmáticas integras, e com perfeita justaposição. As mitocôndrias apresentam excelente estado de preservação, com cristas bem definidas. Barra $=2 \mu \mathrm{m}$. 
Figura 7 - Micrografia eletrônica de tecido paratireoideo humano, de paciente do grupo prevalente, correspondente ao Tempo 3 (tecido fixado após seis horas em meio de transporte). Neste grande aumento notam-se membranas plasmáticas integras, e com perfeita justaposição. As mitocôndrias apresentam cristas intactas e formato normal. Barra $=1 \mu \mathrm{m}$.

Figura 8 - Micrografia eletrônica de tecido paratireoideo humano, de paciente do grupo prevalente, correspondente ao Tempo 4 (tecido fixado após doze horas em meio de transporte). São visualizadas células oxifílicas, com características normais. Notam-se membranas plasmáticas integras, e com perfeita justaposição. As mitocôndrias apresentam bom estado de preservação. Barra $=2 \mu \mathrm{m}$.

Figura 9 - Micrografia eletrônica de tecido paratireoideo humano, de paciente do grupo prevalente, correspondente ao Tempo 4 (tecido fixado após doze horas em meio de transporte). Em destaque células principal, com características normais. Notam-se mitocôndrias com excelente estado de preservação, e cristas bem definidas. Pode-se observar a integridade do envoltório nuclear com os ribossomos aderidos na sua face citoplasmática

Figura 10 - Micrografia eletrônica de tecido paratireoideo humano, de paciente do grupo prevalente, correspondente ao Tempo 5 (tecido fixado após vinte e quatro horas em meio de transporte). As células apresentam-se repletas de vacúolos e não é possível identificar mitocôndrias integras. Barra $=2 \mu \mathrm{m}$.

Figura 11 - Micrografia eletrônica de tecido paratireoideo humano, de paciente do grupo prevalente, correspondente ao Tempo 5 (tecido fixado após vinte e quatro horas em meio de transporte) em maior aumento que na Figura 10. Observar sinais de morte celular, com o citosol opticamente vazio e vacúolos em processo de degeneração. Embora o núcleo esteja aparentemente íntegro, a membrana do envoltório nuclear apresenta perfil irregular e sem os ribossomos que the são característicos. Barra $=1 \mu \mathrm{m}$. 
Figura 12 - Micrografia eletrônica de tecido paratireoideo humano, de paciente do grupo prevalente, correspondente ao Tempo 5 (tecido fixado após vinte e quatro horas em meio de transporte). Além da maioria das mitocôndrias apresentarem formações vacuolares e alterações degenerativas, observar que as células não se apresentam mais envolvidas individualmente por membrana plasmática. Barra $=4 \mu \mathrm{m}$.

Figura 13 - Micrografia eletrônica de tecido paratireoideo humano, de paciente que apresentou preservação em todos os tempos, correspondente ao Tempo 5 (tecido fixado após vinte e quatro horas em meio de transporte), com aumento de 8.900x. Notam-se ausência de edema, a maioria das mitocôndrias apresenta-se com bom aspecto de preservação e com cristas integras. Algumas poucas mitocôndrias apresentarem formações vacuolares e alterações degenerativas. Também é possível observar a boa condição de adesão celular e preservação das membranas plasmáticas. A seta vermelha aponta para desmossomo. Barra $=2 \mu \mathrm{m}$

Figura 14 - Micrografia eletrônica de tecido paratireoideo humano, de paciente que apresentou danos celulares em todos os tempos, correspondente ao Tempo 1 (tecido fixado a fresco, sem contato com o meio de transporte). Nesta micrografia de pequeno aumento, as células apresentaram ruptura das membranas plasmáticas, com dispersão das organelas. Os núcleos em destaque apresentam condensamento da cromatina e edema nuclear. Barra $=10 \mu \mathrm{m}$.

Figura 15 - Micrografia eletrônica de tecido paratireoideo humano, de paciente que apresentou danos celulares em todos os tempos, correspondente ao Tempo 3 (tecido fixado a após imersão em meio de transporte por 6 horas). Além da ruptura das membranas plasmáticas, as mitocôndrias apresentam alterações degenerativas avançadas, com formações vacuolares. Os núcleos em destaque apresentam dissolução da cromatina. Os traços vermelhos envolvem grande formação vacuolar. Barra = $10 \mu \mathrm{m}$. 
Figura16 -Fotomicrografia de tecido paratireoideo humano, de paciente que apresentou danos celulares em todos os tempos, correspondente ao Tempo 5 (tecido fixado a após imersão em meio de transporte por 24 horas). As mitocôndrias apresentam alterações degenerativas avançadas. A seta vermelha aponta para aponta para picnose nuclear, o asterisco vermelho marca área de degeneração tecidual, os asteriscos verdes marcam numerosos vacúolos, e os traços vermelhos demarcam célula oxifílica muito edemaciada. Barra $=20 \mu \mathrm{m}$. 


\section{RESUMO}

Barreira CESR. Análise da ultra-estrutura do tecido paratireóideo humano em solução para preservação de tecidos [tese]. São Paulo: Faculdade de Medicina, Universidade de São Paulo; 2010.

INTRODUÇÃO: A criopreservação de tecido paratireóideo é empregada no tratamento cirúrgico do hiperparatireoidismo secundário nos pacientes com doença renal crônica. Entre a captação do tecido e a criopreservação, realizada em laboratório especializado, o tecido é preservado em solução para cultura de células a $4^{\circ} \mathrm{C}$ (solução para transporte). Não há dados que demonstrem por quanto tempo o tecido paratireóideo humano pode permanecer viável nesta solução, antes de ser criopreservado. Este estudo objetiva avaliar o período de tempo que o tecido da glândula paratireóide hiperplásica de humanos pode permanecer na solução para transporte, sem apresentar danos ultra-estruturais. MÉTODOS: Estudo prospectivo que incluiu 11 pacientes submetidos a paratireoidectomia total com autoimplante heterotópico e criopreservação de fragmentos de tecido paratireóideo. Parte do tecido destinado para exame anatomopatológico foi selecionado para preservação em solução para transporte. Foram definidos 5 períodos relacionados ao tempo de permanência dos fragmentos de paratireóide na solução para transporte. No tempo 1, o material foi fixado a fresco, sem contato com a solução para transporte, este tempo serviu para controle. No tempo 2, os fragmentos de tecido permaneceram imersos na solução para transporte por 2 horas, no tempo 3 , este período foi de 6 horas, e os tempos 4 e 5 , corresponderam a preservação dos fragmento de paratireóide na solução para transporte por 12 e 24 horas respectivamente. Ao final de cada período os fragmentos foram removidos da solução de transporte e fixados com glutaraldeído a $2 \%$, seguido por preparo do material para cortes ultrafinos. A análise por microscopia eletrônica avaliou a adesão celular e a integridade das membranas plasmáticas, dos núcleos e das mitocôndrias, além da presença de edema celular e de vacúolos. RESULTADOS: Dos 11 casos estudados, 10 apresentaram achados ultraestruturais compatíveis com a normalidade nos fragmentos de tecido que permaneceram na solução para transporte por até 12 horas. Em apenas um destes casos, houve preservação das características morfológicas do tecido por 24 horas, na solução para transporte. Em um caso os achados caracterizaram sinais de dano celular irreversível em todos os períodos, inclusive no tempo inicial, em que o tecido foi fixado a fresco, sem contato com a solução para transporte. As alterações das mitocôndrias representaram os danos ultra-estruturais mais constantes nos casos estudados. CONCLUSÃO: A análise da ultra-estrutura do tecido da glândula paratireoide hiperplásica de humanos permite concluir que ocorre manutenção adequada da integridade estrutural do tecido que permanece na solução com meio de cultura de células a $4^{\circ} \mathrm{C}$.até cerca de 12 horas após sua retirada do organismo, na maioria dos casos. 
Descritores: 1. Criopreservação, 2. Paratireóide, 3. Preservação de órgãos, 4. Paratireoidectomia, 5. Auto-implante, 6. Microscopia eletrônica, 7. Hiperparatireoidismo secundário, 8. Hiperparatireoidismo 


\section{SUMMARY}

Barreira CESR. Analysis of the ultrastructure of human parathyroid in solution for preservation of tissue [thesis]. São Paulo: "Faculdade de Medicina, Universidade de São Paulo"; 2010.

BACKGROUND: The cryopreservation of parathyroid tissue is employed in the surgical treatment of secondary hyperparathyroidism in patients with chronic kidney disease. During the period between surgical resection and cryopreservation of tissue, which requires a specialized laboratory, the tissue is stored in a cell culture solution, at $4{ }^{\circ} \mathrm{C}$ (solution for transport from the operating room to the laboratory). There is no data showing for how long the human parathyroid tissue can remain viable in this solution, before being cryopreserved. The present study evaluates the time that the tissue of human hyperplastic parathyroid gland could remain in solution for transportation, without showing ultrastructural damages. METHODS: This prospective study included 11 patients, who underwent total parathyroidectomy with heterotopic autotransplantation and cryopreservation of parathyroid tissue fragments. Part of the tissue intended for pathological examination was selected for storage at solution for transportation. Five periods were defined, related to the storage time of parathyroid fragments at solution for transportation. At time 1, the material was fixed at the time of surgical resection, without contact with the solution for transport, this time was used as control. At time 2 , the fragments of tissue remained stored at the solution for transportation for 2 hours, at time 3, this period was 6 hours, and Times 4 and 5 , corresponded to the parathyroid fragments stored in the transport solution for 12 and 24 hours, respectively. At the end of each period the fragments were removed from the transport solution and fixed with $2 \%$ glutaraldehyde, followed by preparation of material for ultrathin sections. The analysis by electron microscopy was used to evaluate cell adhesion and integrity of plasma membranes, nuclei and mitochondria, and the presence of edema and cell vacuoles. RESULTS: Of the 11 cases studied, 10 showed ultrastructural findings consistent with the normal tissue fragments that remained in the solution to transport up to 12 hours. In only one of these cases, there was preservation of the morphological characteristics of the tissue for 24 hours, at the solution for transportation. In one case, there were findings of marked signs of irreversible cell damage in all periods, including the initial time in which the tissue was fixed at the time of surgical resection, without contact with the solution for transportation. Changes of mitochondria represented the ultrastructural damage more constant in the cases studied. CONCLUSION: The analysis of the ultrastructure of human hyperplastic parathyroid gland tissue shows that, in most cases, ultrastructural integrity is properly maintained in fragments stored up to 12 hours in a solution of cell culture, at $4^{\circ} \mathrm{C}$.

Keywords: 1. Cryopreservation, 2. Parathyroid, 3. Preservation of organs, 4. Parathyroidectomy, 5. Autotransplantation, 6. Electron microscopy, 7. Hyperparathyroidism, 8. Hyperparathyroidism. 

1 INTRODUÇÃO 
As paratireóides são glândulas endócrinas derivadas do endoderma dorsal da terceira e quarta bolsas faríngeas. Medem aproximadamente seis $\mathrm{mm}$ de comprimento e três a quatro $\mathrm{mm}$ de largura, com formato ovóide e achatado, e pesam cada uma entre 30 e $40 \mathrm{mg}{ }^{1}$. São geralmente quatro glândulas em torno de $84 \%$ dos pacientes ${ }^{2,3}$.

As paratireóides são responsáveis pela síntese e secreção de paratormônio (PTH). Este hormônio é secretado predominantemente na forma de uma proteína com 84 resíduos de aminoácidos, denominada molécula intacta ${ }^{4}$. A hipersecreção do paratormônio, pelo aumento do número de células paratireoideas, ou pela hiperfunção das mesmas, caracteriza o hiperparatireoidismo. Este é considerado primário (HPT1) quando ocorre por distúrbio da própria glândula, e secundário (HPT2) quando surge como conseqüência de uma alteração metabólica preexistente. A principal causa de HPT1 é o adenoma, que ocorre em cerca de $90 \%$ dos casos. Trata-se de neoplasia benigna que compromete freqüentemente apenas uma das paratireóides, e somente entre 2 a $5 \%$ dos casos ocorre em duas glândulas paratireoideas ${ }^{5}$. O tratamento adequado é a ressecção das glândulas acometidas.

Em nosso meio o HPT2 é prevalente entre pacientes com insuficiência renal crônica, que realizam tratamento com diálise, e cursam com hiperplasia das paratireóides. Entre 1990 a 2004, quase dois terços dos pacientes submetidos à cirurgia para tratamento do hiperparatireoidismo no Hospital das Clínicas da Universidade de São 
Paulo, apresentavam hiperplasia das paratireoides devido à doença renal crônica, superando o número de pacientes operados por HPT1 ${ }^{6}$.

O mecanismo fisiopatológico exato que induz a proliferação celular das paratireóides na doença renal crônica, ainda não é completamente compreendido. Porém sabe-se que a hipocalcemia, a hiperfosfatemia causada pela retenção de fosfato, e a deficiência da vitamina 1,25diidroxicolecalciferol (calcitriol) são as três principais causas do hiperparatireoidismo na doença crônica renal, entre as alterações metabólicas $^{7}$. Em condições fisiológicas normais há uma interação regulatória entre $\mathrm{PTH}$, cálcio, calcitriol e o fósforo. No HPT2 ocorre o aumento da capacidade secretora das paratireoides, com elevação do PTH e perda dos mecanismos fisiológicos de regulação deste hormônio. O tratamento do HPT2 nos pacientes renais crônicos é iniciado com manejo clínico do doente para manutenção adequada dos níveis de cálcio e fósforo.

Desde o início deste tratamento são instituídas a restrição da dieta de fósforo, a suplementação de cálcio e calcitriol. Os pacientes com hipercalcemia e/ou hiperfosfastemia refratárias ao tratamento clínico inicial ainda podem utilizar quelantes de fósforo, calcimiméticos, como o cinacalcet, e análogos da vitamina $\mathrm{D}^{8}$.

Mais da metade dos pacientes em diálise desenvolvem HPT2, com necessidade de cuidados preventivos e terapêuticos para evitar alterações importantes do cálcio e do fósforo. No entanto, diversos estudos indicam que entre 5 a $38 \%$ destes doentes evoluem para 
necessidade de tratamento cirúrgico ${ }^{9},{ }^{10}$. Em 1996, a Associação Européia de Diálise e Transplante relatou que dentre os pacientes com dez anos em tratamento dialítico, $15 \%$ necessitaram de tratamento cirúrgico com paratireoidectomia, com aumento deste índice para $38 \%$ entre os pacientes com 20 anos de diálise ${ }^{10}$. Dados semelhantes também foram descritos pela Sociedade Japonesa de Terapia Dialítica em 1997, neste artigo Maeda, citado por Tominaga ${ }^{11}$, relatou a necessidade de tratamento cirúrgico em torno de $10 \%$ entre os pacientes em diálise há 10 anos, e 30\% nos pacientes com mais de 20 anos de diálise.

Esses números parecem demonstrar a melhora progressiva na sobrevida dos doentes com insuficiência renal crônica. Em conseqüência, espera-se o aumento do número de doentes com necessidade de tratamento cirúrgico por HPT2.

Os dados mais recentes do censo da Sociedade Brasileira de Nefrologia $^{12}$ em março de 2008, apontam uma estimativa de aproximadamente 87.044 pacientes com insuficiência renal crônica em tratamento com diálise neste período, no Brasil. A região Sudeste comporta $57,4 \%$ destes doentes, seguida pelas regiões Nordeste com $19,1 \%$, Sul com $15,4 \%$, Centro-Oeste com $5,8 \%$, e Norte com $2,3 \%$ dos doentes. De acordo com dados referidos anteriormente, pelo menos $5 \%$ destes pacientes evoluem com necessidade de tratamento cirúrgico. São números expressivos que merecem a devida atenção dos gestores de saúde. 
Nos pacientes com HPT2, a terapêutica cirúrgica é instituída quando não há mais possibilidade para controle clínico adequado da calcemia e da fosfatemia, com aumento progressivo dos níveis de PTH e surgimento de sinais e sintomas que causam morbidade e elevam os índices de mortalidade destes pacientes ${ }^{13}$.

O tratamento cirúrgico inclui paratireoidectomia total com ou sem auto-implante heterotópico de fragmentos de paratireóide, e a paratireoidectomia subtotal. Nas paratireoidectomias totais sem autoimplante ocorre hipoparatireoidismo definitivo, com necessidade de suplementação de altas doses de cálcio e vitaminas D. O fator de preocupação para esta modalidade de tratamento está no aumento da incidência de doença óssea adinâmica, devido aos níveis indetectáveis, ou muito baixos de PTH. Em longo prazo, a ausência de PTH está associada com osteoporose, e fraturas ósseas patológicas, sobretudo devido à diminuição da atividade dos osteócitos e da remodelação óssea ${ }^{14}$. Alguns poucos trabalhos não evidenciaram estas morbidades associadas à ausência do $\mathrm{PTH}^{15,16}$. Nas paratireoidectomias subtotais são ressecadas três glândulas inteiras e metade a dois terços da quarta glândula. Ocorre a preservação de um segmento de tecido paratireoideo em seu próprio leito com sua irrigação sanguínea intacta, com intenção de manter níveis mais baixos de PTH. A taxa de recidiva do hiperparatireoidismo observada com esta técnica é elevada ${ }^{17}$, com risco aumentado de iatrogenias em caso de nova abordagem cirúrgica $^{18}$. 
A técnica utilizada com preferência pela maioria dos especialistas atualmente no Brasil é a paratireoidectomia total com autotransplante heterotópico de fragmentos das paratireoides entre as fibras musculares da região pré-esternal ${ }^{19}$ ou do músculo braquioradial ${ }^{20}$. Esta última opção é a técnica de escolha utilizada no Serviço de Cirurgia de Cabeça e Pescoço do Hospital das Clínicas da Universidade de São Paulo (HCFMUSP).

Apesar dos primeiros relatos de autotransplante de tecido paratireoideo terem ocorrido em 1909 com Halsted, que realizou o procedimento em cães, e em 1926 com Lahey, que reimplantou tecido paratireoideo ao notar desvascularização desta glândula durante tireoidectomia, ambos os autores utilizaram tecido a fresco, e aparentemente sadio. Só a partir de 1975, com Wells ${ }^{21}$, surgiram publicações com relato de autotransplante de paratireóides em humanos, no tratamento do hiperparatireoidismo. Desde então esta técnica vem sendo empregada na prática clínica para prevenir o hipoparatireoidismo nos casos de ressecções totais das paratireóides.

A taxa de sucesso do autotransplante com tecido a fresco no HPT2 é bastante variável, com publicações que indicam mal funcionamento do enxerto em até $50 \%$ dos $\operatorname{casos}^{22}$, até a autores como Tominaga, que em 2005, relatou menos de $10 \%$ destes pacientes com nível sérico de PTH menor que $60 \mathrm{pg} / \mathrm{ml}$ em 10 anos após a cirurgia ${ }^{23}$. A maioria das publicações indica índices de sucesso próximos a $83 \%$ 24, 25, 26. 
O índice de insucesso demonstrou a necessidade de novos métodos para diminuir a possibilidade de hipoparatireoidismo definitivo. A partir de 1977 Wells e colaboradores ${ }^{27}$ difundiram o transplante heterotópico de paratireoide após criopreservação de parte do tecido. Esta conduta é recomendável nos dias atuais, visto que se podem resguardar os pacientes da possibilidade de permanecer com hipoparatireoidismo definitivo. A taxa de sucesso do autotransplante de tecido paratireoideo criopreservado vária entre 17 a $64 \%{ }^{28,29,30,31}$, tendo em nosso meio um índice em torno de $40 \%{ }^{32}$.

No Serviço de Cirurgia de Cabeça e Pescoço do HCFMUSP, após a ressecção cirúrgica, o tecido paratireoideo hiperplásico é devidamente mensurado. Parte deste tecido é fragmentado, e implantado no meio de tecido muscular, parte preparado para criopreservação e a maior parte da paratireóide, enviada para estudo anatomopatológico ${ }^{33}$.

Ocorre que entre a captação do tecido e a criopreservação propriamente dita, o tecido é acondicionado em recipiente contendo solução para cultura de células e mantido em condições de hipotermia a aproximadamente 4 graus centigrados. Na pratica clínica este meio de cultura de células é chamado de meio de transporte. Nestas condições o tecido é transportado até laboratório específico, onde passa por um preparo, para então ser criopreservado. Trata-se de laboratório especializado e com alto custo para montagem e manutenção. Não se sabe com certeza, por quanto tempo este tecido pode manter-se viável, 
enquanto acondicionada na solução com meio de cultura a $4^{\circ} \mathrm{C}$, antes do processo de criopreservação.

O processo de criopreservação necessita de cuidados logísticos que demandam equipe dedicada e custos operacionais, que dificultam sua execução fora dos centros de excelência. $O$ fato de conhecermos a quantidade de tempo que o tecido paratireoideo humano permanece viável na solução com meio de cultura e hipotermia, pode facilitar o gerenciamento de unidades estratégicas de criopreservação, com concentração dos custos para facilitar a utilização do método por centros mais distantes. Em um país de grandes dimensões territoriais e grandes variações de práticas médicas loco - regionais este conhecimento pode auxiliar no planejamento e uso racional dos recursos do sistema de saúde.

A análise morfológica do tecido paratireoideo com uso da microscopia óptica não se mostra efetiva para predizer a viabilidade do mesmo ${ }^{26}$, provavelmente porque os eventos esperados, como autólise e formações vacuolares, são eventos mais tardios. A utilização da microscopia eletrônica, para analisar a ultra-estrutura celular, poderia ser útil, já que é capaz de descrever alterações mitocondriais e em outras organelas citoplasmáticas, além de avaliar alterações na adesão celular, já que estes são eventos precoces no processo de morte celular. 
2 OBJETIVOS 
Este estudo tem o objetivo de avaliar morfologicamente as alterações ultra-estruturais do tecido paratireoideo humano acondicionado em solução com meio de cultura de células e hipotermia (meio de transporte), antes do processo de criopreservação. A análise por microscopia eletrônica objetiva avaliar o grau de destruição celular que o tecido paratireoideo humano apresenta em solução com meio de cultura e hipotermia, em tempos determinados, antes de ser criopreservado. As questões a seguir são de interesse neste estudo:

1 - Por quanto tempo o tecido paratireoideo humano permanece com sua integridade ultra-estrutural, na solução com meio de cultura de células a 4 graus centigrados?

2 - Existe diferença na avaliação morfológica por microscopia eletrônica (ME) nos diferentes tempos de espera entre si e em relação à paratireoide a fresco?

3 - Por até quanto tempo, pode-se conservar o tecido paratireoideo humano no meio de transporte, com manutenção adequada da sua morfologia ultra-estrutural? 
3 REVISÃO DA LITERATURA 


\subsection{Ultra-estrutura do tecido paratireoideo humano}

A morfologia ultra-estrutural do tecido paratireoideo humano têm suas primeiras descrições publicadas em 1969, com Roth ${ }^{34}$, e em 1972, com Altenähr ${ }^{35}$. Tanto detalhes da ultra-estrutura da glândula normal, quanto em diversas alterações fisiológicas e patológicas foram descritas. As paratireóides são revestidas por uma fina cápsula fibrosa que penetra no parênquima glandular juntamente com uma rica rede de capilares. Nos adultos o parênquima da glândula paratireóide normal é formado por células principais, em diferentes estágios de atividade secretora, por células oxifílicas, e por células oxifilicas transicionais. O interstício é composto por fibras de colágeno e células de gordura ${ }^{36}$. As células principais e medem entre 6 a $12 \mu \mathrm{m}$ de diâmetro, com citoplasma levemente eosinofílico e com núcleo central e pequeno, hipercromático. Podem-se distinguir células principais ativas e inativas. Estas últimas podem se apresentar vacuoladas a microscopia óptica, devido ao seu citoplasma repleto de gotículas de gordura, glicogênio e lisossomos. As células ativas apresentam características ultra-estruturais que se relacionam com sua atividade funcional, que é produzir e secretar o paratormônio. Por isso seu citoplasma contém retículos endoplasmáticos rugosos e complexos de Golgi proeminentes. As células oxifílicas surgem a partir da puberdade, e aumentam em número com o avanço da idade. São pouco maiores que as células principais, com membrana celular demarcada, núcleo pequeno e hipercromático, abundante citoplasma granular eosinofílico, quase todo repleto de mitocôndrias e com 
complexos de Golgi e retículos endoplasmáticos pouco evidentes. As células oxifílicas transicionais tem seu citoplasma ocupado, em torno de $50 \%$, por mitocôndrias. Estas células também apresentam reticulo endoplasmático rugoso, e complexo de Golgi proeminentes, além de grânulos pró-secretores e secretores ${ }^{34,35,36,37 .}$

As células do parênquima do tecido paratireoideo encontram-se em justaposição, detalhe comum a células glandulares epiteliais. As organelas envolvidas com a síntese e estocagem hormonal apresentamse proeminentes, sobretudo quando as paratireoides estão com atividade secretória aumentada. Alterações morfológicas associadas à hipersecreção hormonal são notadas com proliferação dos ribossomos, e aumento do tamanho dos retículos endoplasmáticos rugosos e dos complexos de Golgi. As mitocôndrias apresentam-se com matriz elétrondensa, e com formações lamelares em seu interior, que são denominadas cristas $^{34,35,36,37}$.

Nos pacientes com HPT2 ocorrem aumento do tamanho glandular e também algumas alterações ultra-estruturais. O tecido paratireoideo exibe os mesmos tipos celulares, porém a quantidade de células oxifílicas e oxifílicas transicionais é muito maior, em relação à quantidade de células principais. As mitocôndrias podem estar aumentadas, e podem apresentar formato bizarro e atipia na morfologia das cristas. O complexo de Golgi apresenta-se aumentado e com vacúolos e vesículas proeminentes. E o reticulo endoplasmático rugoso também se apresenta mais desenvolvido com arranjos paralelos e esféricos ${ }^{34,37}$. 


\subsection{Criopreservação}

O primeiro relato de criopreservação de tecido paratireoideo ocorreu em 1950, quando Blumenthal e Walsh coletaram fragmentos de paratireoide de porcos e preservaram o material por 24 horas a $70^{\circ} \mathrm{C}$ negativos. No décimo terceiro dia após o reimplante os tecidos foram biopsiados, e a análise histopatológica apontou viabilidade dos fragmentos de paratireóide ${ }^{38}$. Os esforços para desenvolvimento das técnicas de criopreservação esbarraram no dano celular causado pela exposição a temperaturas muito baixas, principalmente pela formação de cristais de gelo no tecido congelado. Em 1954, Lovelock e Polge descreveram os resultados com uso de glicerol, como agente crioprotetor em espermatozóides ${ }^{39}$. E em 1959, Lovelock e Bishop ${ }^{40}$ publicaram os benefícios do dimetil sulfóxido (DMSO) em prevenir os danos celulares durante a criopreservação. Este estudo possibilitou que Sonoda e colaboradores (1968) relatassem o sucesso obtido com o reimplante de tecido paratireoideo canino, após criopreservação por sete dias. Sonoda ${ }^{41}$ utilizou o DMSO a $15 \%$ neste estudo, e conseguiu comprovar a importância da utilização de agentes crioprotetores.

Saxe ${ }^{25}$ em uma ampla revisão da literatura, publicada em 1984 , creditou a Russell e Polge ${ }^{42}$, importantes experimentos, tanto com agentes crioprotetores, quanto com velocidade para congelamento e estocagem. Segundo Saxe, estes autores obtiveram melhores resultados com tecido paratireoideo de ratos, quando utilizaram congelamento lento, com uma taxa de 1 grau centigrado por minuto, até $196^{\circ} \mathrm{C}$ negativos. 
Wells e Christiansen ${ }^{43}$ publicaram um artigo em 1974, no qual avaliaram o processo de criopreservação de tecido paratireoideo de ratos Fischer. Eles utilizaram DMSO a 10\%, como agente crioprotetor, congelamento lento até 80 graus centigrados negativo, seguido de congelamento rápido e estocagem a $196^{\circ} \mathrm{C}$ negativos. Os autores conseguiram demonstrar função in vivo do tecido criopreservado por períodos de 3 a 9 meses. No mesmo artigo Wells e Christiansen também avaliaram o efeito de alguns fatores relacionados à manipulação do tecido paratireoideo de ratos. As paratireoides obtidas destes ratos foram separadas em grupos, e submetidas a dois tipos de tratamento do tecido. No primeiro tipo de tratamento do tecido, as paratireoides foram colocadas em leito muscular sem suprimento sanguíneo, por períodos de 1,3 e 6 horas. No segundo tipo, as paratireoides foram colocadas em solução de meio de cultura de células, por períodos de 3, 6, 9 e 12 horas, foi utilizada a solução para meio de cultura de Waymouth, a temperatura ambiente. Ao fim de cada um destes períodos, as paratireoides foram implantadas em ratos paratireoidectomizados e hipocalcemicos, e foi averiguado o restabelecimento dos níveis sanguíneos de cálcio em todos estes grupos de ratos, em todos os períodos citados. Foi comprovada funcionalmente, a resistência e a viabilidade do tecido paratireoideo dos ratos Fischer a todos os períodos estudados.

Somente em 1977 foi publicada a primeira experiência bem sucedida com autotransplante de tecido paratireoideo humano criopreservado, onde Wells e colaboradores ${ }^{27}$ demonstraram a viabilidade do enxerto, 
dois anos após o implante. Os fragmentos de paratireoide permaneceram congelados em nitrogênio líquido por seis semanas, e os autores comprovaram a viabilidade do enxerto, tanto por análise ultra-estrutural (microscopia eletrônica), quanto por testes funcionais, através da medida de PTH no membro que foi realizado o implante. Até os dias atuais a maioria dos especialistas utiliza a criopreservação com técnicas semelhantes à relatada por Wells em 1977. Apesar de melhorias e modificações nos métodos e materiais referentes à criopreservação, este processo ainda pode ser considerado empírico.

\subsection{Soluções para Meios de Cultura}

Desde o início dos experimentos com criopreservação houve preocupação em manter os fragmentos de paratireoide em meio de cultura para células, mantendo um ambiente adequado para manutenção da vitalidade celular. Estes meios de cultura conferem osmolaridade e $\mathrm{pH}$ adequados, além de conterem aminoácidos, vitaminas, sais minerais e nutrientes essenciais para as células. Os estudos publicados por Brennan e colaboradores em 1978 e 1979, relataram o acondicionamento dos fragmentos de paratireoide em uma mistura composta por $10 \%$ de DMSO, $10 \%$ de soro autólogo, e $80 \%$ de meio de cultura ${ }^{44,45 .}$ O meio de cultura de célula utilizado foi o RPMI 1640, desenvolvido por Moore e colaboradores no Roswell Park Memorial Institute, Buffalo, New York. Desde então diversos autores utilizam uma variação desta mistura, ou uma variação dos componentes da solução de cultura, para acondicionamento do tecido para criopreservação. Existem várias 
soluções utilizadas para cultura de células, e embora com composições diferentes, todas as soluções objetivam prevenir edema, nutrir e preservar a morfologia e a função celular. Não existe consenso sobre qual a melhor solução para preservação celular ou tecidual, e existem poucos artigos na literatura, que comparam as diversas soluções ${ }^{46,}{ }^{47}$. No caso de preservação de tecido paratireoideo humano, não existem artigos que comparem quais soluções apresentam melhores resultados. Embora cada instituição tenha seus protocolos para criopreservação, estes são bastante variáveis em relação à formulação dos materiais utilizados. 0 RPMI 1640 e o DMEM (Dulbecco`s modified Eagle`s medium) são as soluções para meio de cultura de células utilizadas mais amplamente.

O DMEM foi desenvolvido por Renato Dulbecco e Marguerite Vogt, a partir da fórmula do EMEM (Eagle`s minimal essencial médium), e têm quatro vezes mais aminoácidos, vitaminas e glicose, do que a fórmula original $^{48}$. Esta solução para cultura de células tem características muito semelhantes ao RPMI 1640. Desde 1996 várias publicações demonstram a utilização do DMEM para preservação de tecido paratireoideo humano ${ }^{49}$ $50,51,52$

O soro autólogo foi utilizado com freqüência desde as publicações de Brennan, porém pesquisas realizadas a partir de 1985 demonstram que o soro obtido do feto bovino tem quantidades maiores de fatores de crescimento ${ }^{53}$. O soro fetal bovino tem mais de mil componentes em sua formulação, sendo os fatores de crescimento e de proliferação celular, os de maior importância para soluções de cultura de células. A primeira 
publicação apontando a utilização de soro fetal bovino adicionado à solução de criopreservação para tecido paratireoideo ocorreu em 1999 com Tsuji e colaboradores ${ }^{52}$. Estes autores utilizaram meio de cultura suplementados por $10 \%$ de soro fetal bovino, e em análise por citometria de fluxo concluíram boa viabilidade das células paratireoideas, além de baixa antigenicidade do meio de cultura estudado.

De acordo com a experiência de cada serviço, podem-se adicionar uma variedade de substancias, as soluções, para potencializar algum efeito desejado. Antibióticos, antifúngicos, e soluções tampão, são utilizados amplamente em soluções para cultura de células e para preservação de órgãos. Apesar do efeito já reconhecido na prática clínica, a maior parte destas substâncias é adicionada empiricamente na formulação do meio de cultura de células.

\subsection{Microscopia eletrônica de transmissão}

O primeiro microscópio eletrônico de transmissão foi construído em 1931, na Alemanha por Ernst Ruska e Max Knoll. Ao invés de utilizar luz, este microscópio emprega feixes de elétrons para obtenção da imagem, e nos dias atuais tem uma resolução quarenta mil vezes melhor que o microscópio óptico.

Em 1937 Castleman e Mallory publicaram um estudo baseado na microscopia óptica de paratireoides em doentes com hiperparatireoidismo, devido à insuficiência renal crônica ${ }^{54}$. A partir deste trabalho e de estudos subseqüentes, ficou clara a relação da hiperplasia das paratireoides em pacientes com doença renal crônica. As primeiras publicações com 
microscopia eletrônica, detalhando o aspecto ultra-estrutural do tecido paratireoideo com hiperplasia em pacientes com doença renal crônica, foram em 1964 por Sheldon e col., e em 1969 e 1970 por Roth e col., onde os autores descreveram os tipos celulares mais freqüentes, as células principais e as células oxifílicas. Todos esses tipos formando estroma fibroso nodular, com preservação das características individuais da ultra-estrutura das células ${ }^{55,56,57}$.

Wells e colaboradores ${ }^{21}$ foram os primeiros a publicar a utilização da microscopia eletrônica com intenção de avaliar a viabilidade do implante de tecido paratireoideo humano. Neste estudo 11 pacientes foram avaliados um ano após paratireoidectomia total com auto-implante imediato de fragmentos de paratireóide na musculatura do antebraço. Entre os 11 pacientes 9 apresentaram normocalcemia, e não necessitavam de reposição de cálcio. Os 11 pacientes foram submetidos à biópsia do implante, e todos apresentaram arquitetura glandular normal, inclusive com demonstração de grânulos secretores.

Em 1977 Wells e col. ${ }^{27}$ também utilizaram a microscopia eletrônica para avaliar a viabilidade do implante autólogo heterotópico de tecido paratireoideo previamente criopreservado. Wells analisou a ultra-estrutura celular após biópsia do implante, e não constatou danos estruturais nas células estudadas. A função do implante também foi comprovada pela normocalcemia, e pela medida do gradiente de concentração do PTH entre os membros com e sem implante. 
Em um relato de casos, Montenegro e colaboradores ${ }^{58}$ realizaram microscopia eletrônica em parte do material descongelado para reimplante. Nos dois casos estudados os fragmentos de paratireóide foram criopreservados por 21 e 30 meses. Ambos pacientes cursaram com sucesso na função do implante, sem necessidade para reposição de cálcio e calcitriol após 12 meses de seguimento. O estudo com microscopia eletrônica em parte dos fragmentos descongelados para implante demonstrou que não existiam danos ultra-estruturais no material utilizado, mesmo após criopreservação por longo período. 


\section{MÉTODOS}


O projeto de pesquisa foi avaliado pela Comissão de Ética para Análise de Projetos de Pesquisa (CAPPesq) do HCFMUSP. Este projeto, protocolado na CAPPesq com o $n^{\circ}$ 0222/09, foi aprovado em 01 de abril de 2009. Os pacientes passaram a fazer parte deste estudo somente após concordarem e assinarem o termo de consentimento informado.

Foram incluídos 11 pacientes, com idades entre 32 e 62 anos, com hiperparatireoidismo secundário devido à insuficiência renal crônica. Todos com indicação de tratamento cirúrgico para o HPT2. A cirurgia foi indicada em pacientes com níveis persistentemente altos de PTH (maior que $800 \mathrm{pg} / \mathrm{ml}$ ), com hipercalcemia e/ou hiperfosfatemia refratários ao tratamento clínico.

Os pacientes foram submetidos à paratireoidectomia total com autoimplante heterotópico de tecido paratireoideo em membro superior, que não porta fistula arteriovenosa, com criopreservação de tecido paratireoideo. O estudo incluiu os pacientes operados pelo Serviço de Cirurgia de Cabeça e Pescoço do HCFMUSP, entre oito de abril a cinco de outubro de 2009.

Dez pacientes foram submetidos à paratireoidectomia total, com ressecção de quatro glândulas. Durante o procedimento cirúrgico todas as glândulas foram identificadas antes de serem ressecadas. Estas paratireoides permaneciam com seus pedículos intactos, até o momento da ressecção. Um paciente já havia se submetido à paratireoidectomia total, sem auto-implante, há mais de dez anos, em outro serviço, e apresentava recidiva do hiperparatireoidismo. Os exames pré-operatórios 
deste paciente apontavam para recidiva com uma única paratireoide cervical. Este paciente foi submetido à ressecção desta paratireoide.

Logo em seguida à ressecção cirúrgica, parte do tecido paratireoideo foi reimplantado no músculo braquioradial, em loja única, parte foi criopreservado, parte do material encaminhado a exame anatomopatológico de rotina, e outra parte foi utilizada para inclusão neste estudo.

O tecido selecionado para inclusão neste trabalho foi seccionado em pequenos fragmentos de aproximadamente 2 milímetros, semelhantes aos fragmentos que são preparados para criopreservação e para o autoimplante. Alguns fragmentos foram fixados a fresco, para servirem de controle, e o restante dos fragmentos foram colocados em solução para cultura de células (meio de transporte) dentro de tubo plástico e imediatamente acondicionado em recipiente térmico com gelo a aproximadamente $4^{\circ} \mathrm{C}$. Um termômetro foi utilizado para averiguação da temperatura, que foi mantida nesta marca, para preservação adequada da solução e para proporcionar a hipotermia desejada para preservação do tecido. Após a ressecção da glândula paratireóide, o preparo do material com a fragmentação do tecido foi imediato, para ser evitado dano devido à isquemia.

\subsection{A solução de transporte}

A solução utilizada para meio de transporte foi a solução para cultura de células DMEM (Dulbecco`s Modified Eagle`s Medium, Gibco BRL, Rockville, EUA) adicionada de $500 \mu \mathrm{g} / \mathrm{mL}$ de estreptomicina e 
$500 \mu \mathrm{g} / \mathrm{mL}$ de ampicilina, mais $3 \mu \mathrm{g} / \mathrm{mL}$ anfotericina B e Hepes $25 \mathrm{mM}$

(Sigma, Saint Louis, EUA). O Hepes foi adicionado para potencializar o sistema tampão, adequado para culturas com $\mathrm{pH}$ ideal a 7.2. A tabela 1 descreve os componentes da fórmula da solução DMEM.

Tabela 1 - Composição do meio de cultura DMEM

\begin{tabular}{|lrlr|}
\hline SAIS INORGÂNICOS & g/L & VITAMINAS & g/L \\
CaCL2 (anídrico) & 0.20000 & tiamina.HCL & 0.00400 \\
KCL & 0.40000 & pantotenato de cálcio & 0.00400 \\
MgSO4 (anídrico) & 0.09767 & cloreto de colina & 0.00400 \\
NaCl & 6.40000 & ácido fólico & 0.00400 \\
NaHCO3 & 3.70000 & i-inositol & 0.00720 \\
NaH2PO4·H2O & 0.12500 & nicotinamida & 0.00400 \\
Fe(NO3)3·9H2O & 0.00010 & riboflavina & 0.00040 \\
AMINOÁCIDOS & g/L & piridoxina.HCL & 0.00400 \\
L-arginina.HCL & 0.08400 & & \\
L-tirosina & 0.10379 & OUTROS & mg/L \\
L-serina & 0.04200 & glicose & 4.50000 \\
L-cistina & 0.06260 & vermelho de fenol & 0.01500 \\
L-triptofano & 0.01600 & & \\
L-glutamina & 0.58400 & & \\
L- glicina & 0.03000 & & \\
histidina.HCL.H2O & 0.04200 & & \\
L-isoleucina & 0.10500 & & \\
L-leucina & 0.10500 & & \\
L-lisina.HCL & 0.14600 & & \\
L-metionina & 0.03000 & & \\
L-fenilalanina & 0.06600 & & \\
L-valina & 0.09400 & & \\
L-treonina & 0.09500 & & \\
& & & \\
& & & \\
\end{tabular}

FONTE: Current Protocols in Cell Biology 2000, Supplement $6^{58}$

A figura 1 demonstra a solução de transporte citada acima, já acondicionada em tubos plásticos, e pronta para receber os fragmentos 
de tecido paratireoideo. Esta solução permaneceu em recipiente com gelo, a aproximadamente $4^{\circ} \mathrm{C}$.

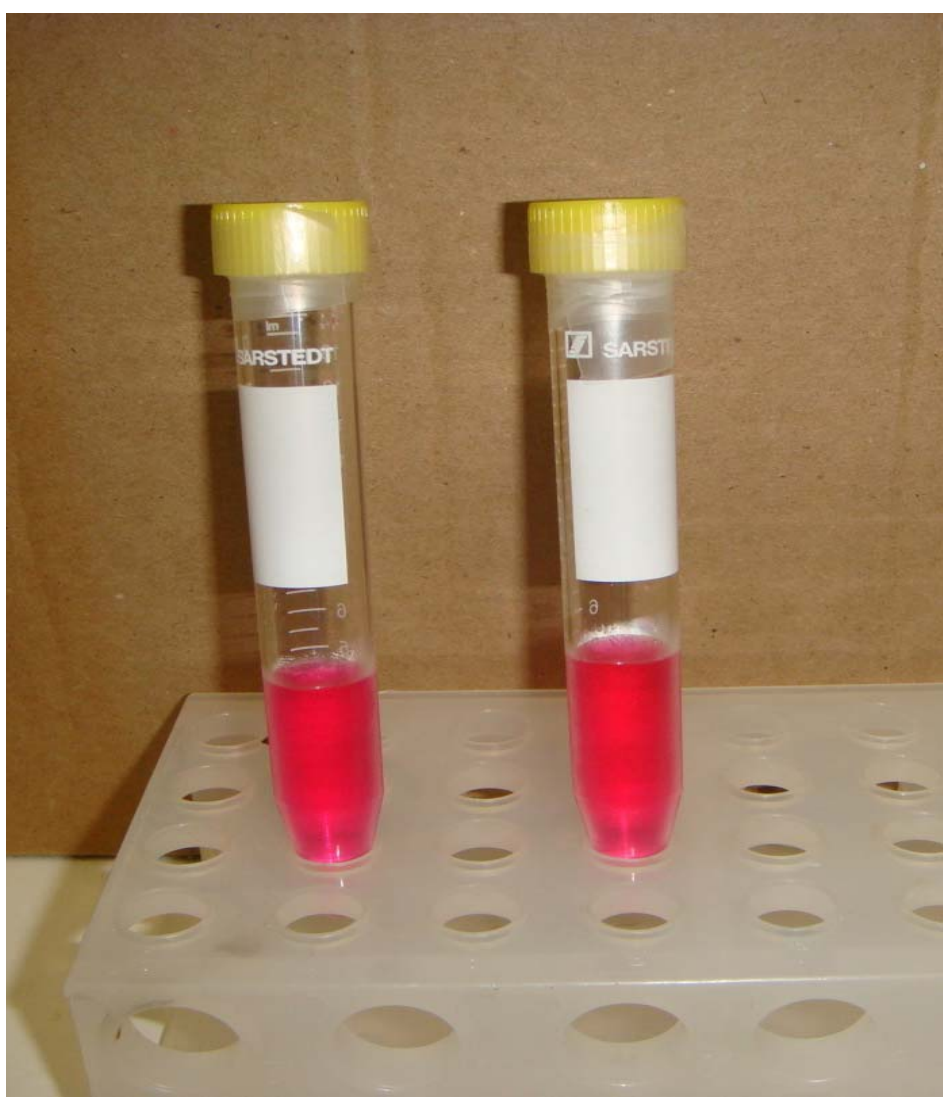

Figura 1 - Fotografia de recipientes contendo a solução para transporte

\subsection{A fixação do material}

O processamento de fixação do material para $M E$ é diferenciado. Primeiro o glutaraldeído a $2 \%$ é preparado em solução tampão fosfato $0,15 \mathrm{M}$, com ph 7.2 , e conservado sob congelamento. Esta solução deve ser descongelada logo antes de adicionarmos os fragmentos de paratireoide (a solução descongela facilmente com o calor das mãos). Após a colocação dos fragmentos de paratireoide nesta solução, estes permaneceram imersos por 2 horas em temperatura ambiente. Em cada frasco foram colocados dois fragmentos de paratireoide, cada um destes medindo aproximadamente $1 \times 1 \mathrm{~mm}$. Estes 
fragmentos permaneceram imersos no glutaraldeído, a temperatura ambiente, por exatamente duas horas. Após este período o material era retirado da solução de glutaraldeído e lavado com solução de sacarose. Esta solução de sacarose é preparada com 200 mililitros de água destilada, 14,6 gramas de sacarose e 1,2 gramas de cloreto de sódio (solução de lavagem). Após lavagem com esta solução, os fragmentos de paratireoide permaneciam imersos na própria solução de sacarose por no máximo 40 horas. Dentro deste prazo os fragmentos foram removidos da solução de lavagem e colocados em solução de tetróxido de ósmio a 1\%, por uma hora sobre refrigeração, quando então foram novamente lavados com solução de sacarose e imersos em solução de acetato de uranila, onde permaneceram por aproximadamente 12 horas, também sobre refrigeração.

\subsection{A fixação do material acondicionado em meio de transporte}

Foram determinados cinco períodos de tempo, para início do processo de fixação do tecido paratireoideo. O tempo 1 é referente a fixação do tecido a fresco, e serviu para controle. Nos demais tempos, os fragmentos de paratireoide permaneceram imersos na solução de transporte a aproximadamente 4 graus Centigrados, e ao fim de cada intervalo de tempo os fragmentos eram removidos da solução e fixados pelo método descrito anteriormente. A tabela 2 resume a definição dos tempos determinados para estudo. 
Tabela 2 - Tempos de imersão do tecido em meio de transporte Tempo 1, tecido paratireoideo fixado a fresco, sem contato com meio de transporte (controle).

Tempo 2, tecido paratireoideo imerso duas horas em meio de transporte. Tempo 3, tecido paratireoideo imerso seis horas em meio de transporte. Tempo 4, tecido paratireoideo imerso doze horas em meio de transporte. Tempo 5, tecido paratireoideo imerso vinte e quatro horas em meio de transporte

Após a permanência dos fragmentos de paratireoide na solução de transporte, ao término de cada um destes períodos, o material foi removido desta solução e fixado de acordo com a técnica citada anteriormente. Foram obtidos fragmentos para todos os tempos, em todos pacientes.

\subsection{Preparo do material para microscopia eletrônica de transmissão}

Após a fixação para ME, já descrito anteriormente, o material passou por processo de desidratação seriada em banhos de acetona, a concentrações progressivamente maiores até 100\%, além de banhos em óxido de propileno. A tabela 3 resume o processo de desidratação, de acordo com protocolo do Serviço de Microscopia eletrônica da Faculdade de medicina da Universidade de São Paulo. 
Tabela 3 - Resumo do processo de desidratação para ME

\begin{tabular}{|ll|}
\hline Preparo & Tempo \\
1 banho de acetona $30^{\circ}$ & 10 minutos \\
1 banho de acetona $70^{\circ}$ & 10 minutos \\
1 banho de acetona $95^{\circ}$ & 15 minutos \\
2 banhos de acetona $100^{\circ}$ & 15 minutos cada \\
2 banhos de óxido de propileno & 15 minutos cada \\
\hline
\end{tabular}

Em seguida à desidratação foi realizada a inclusão dos fragmentos de paratireoide na resina. $O$ processo foi iniciado pela colocação dos fragmentos de paratireoide em uma mistura de óxido de propileno e resina, na proporção 1:1, durante 2 a 3 horas. Logo após os fragmentos foram colocados em resina pura, deixados na estufa a 37 graus centigrados, por uma hora, e em seguida posicionados em pequenos envelopes, para formação de blocos, onde estes foram levados novamente a estufa a 60 graus centigrados, por 72 horas. A tabela 4 demonstra a composição da resina.

Tabela 4 - Composição da resina

\begin{tabular}{|ll|}
\hline Composto & Quantidade \\
Araldite CY-205 & $11,4 \mathrm{~g}$ \\
Anidrido dodecenil succínico (DDSA) & $8,0 \mathrm{~g}$ \\
DMP 30 (2,4,6-tri(dimethylaminoethyl)phenol) & $0,6 \mathrm{ml}$ \\
Dibutil fitalato & $0,05 \mathrm{ml}$ \\
\hline
\end{tabular}


Uma vez que os fragmentos de paratireoide já se encontravam em blocos de resina, os mesmos foram encaminhados para cortes ultrafinos, e posicionados em micro telas de cobre, de três milímetros e 200 mesh na superfície, onde receberam coloração. A tabela 5 resume o processo de coloração da tela de cobre, de acordo com o protocolo utilizado pelo laboratório de microscopia eletrônica da Faculdade de Medicina da Universidade de São Paulo. Após todo o processo de coloração o material ficou pronto para análise, e foi colocado em uma pequena caixa plástica, específica para armazenamento das micro-telas de cobre, chamada "grid".

Tabela 5 - Processo de coloração das telas de cobre

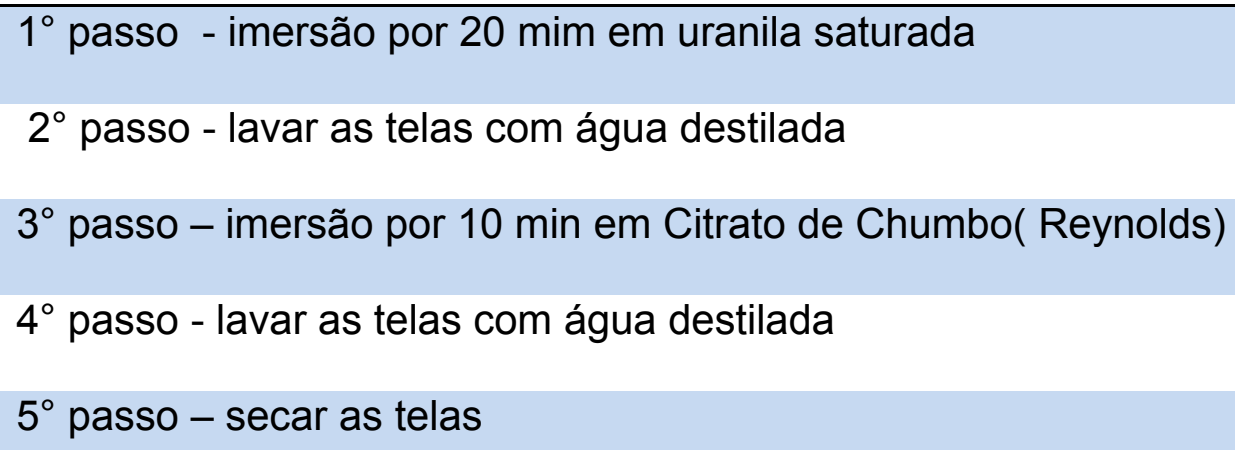

\subsection{Análise por microscopia eletrônica}

Todo material foi processado no Centro Multiusuário de Microscopia Eletrônica da Faculdade de Medicina da Universidade de São Paulo e analisado em microscópio eletrônico de transmissão Tecnai 10 da Philips localizado no Instituto do Coração do Hospital das Clínicas da Faculdade de Medicina da Universidade de São Paulo. Todas as micro-telas foram analisadas em três aumentos. A ultra-estrutura foi visualizada nos 
aumentos de $3.700 \times, 8.900 x$, e $30.000 x$, para análise descritiva do material.

As principais características ultra-estruturais avaliadas foram; a integridade das membranas plasmáticas, a adesão celular, as alterações relacionadas à morfologia das mitocôndrias, e as alterações nucleares. Também foi observada a existência de vacúolos intracitoplasmáticos e a presença de edema celular. A tabela 6 aponta as características avaliadas pela análise ultra-estrutural.

Tabela 6 - Características avaliadas pela análise ultra-estrutural Integridade da membrana plasmática e adesão celular
Integridade das mitocôndrias, características das cristas
Integridade nuclear
Presença de vacúolos intracitoplasmáticos

Edema celular 
5 RESULTADOS 
Entre preparados celulares obtidos dos onze pacientes e analisados pela microscopia eletrônica de transmissão, foram observados três tipos diferentes de resposta, em relação ao tempo de imersão dos fragmentos de paratireoide no meio de transporte. Nove pacientes apresentaram resultados semelhantes em todos os tempos estudados, e estes foram denominados como grupo prevalente. Os pacientes deste grupo apresentaram achados ultra-estruturais compatíveis com normalidade morfológica, tanto nas características do meio intracelular, quanto no aspecto intercelular, nos primeiros 4 tempos estabelecidos, que corresponde à permanência dos fragmentos de paratireoide no meio de transporte por 12 horas. As figuras 2, 3, 4, 5, 6, 7, 8 e 9 ilustram a análise dos fragmentos de paratireoide neste grupo de pacientes, nos quatro primeiros tempos. Nestas figuras são evidenciadas células de tecido paratireoideo com integridade das membranas plasmáticas, e em justaposição, como se espera de células epiteliais glandulares. Tanto as células principais, quanto as oxifílicas apresentam mitocôndrias morfologicamente normais, com a matriz bastante elétron-densa e com cristas íntegras. Os núcleos também de aspecto normal, com cromatina frouxa e formato arredondado a oval. No citoplasma destas células podem-se evidenciar os retículos endoplasmáticos com aspecto granular, com os ribossomos bem aderidos. Neste grupo de pacientes não foi observado edema celular, nem formação de vacúolos intracitoplasmáticos. Estas características apontam para preservação da 
integridade ultra-estrutural, nestes fragmentos de tecido paratireoideo, imersos no meio de transporte a $4^{\circ} \mathrm{C}$, por 12 horas.

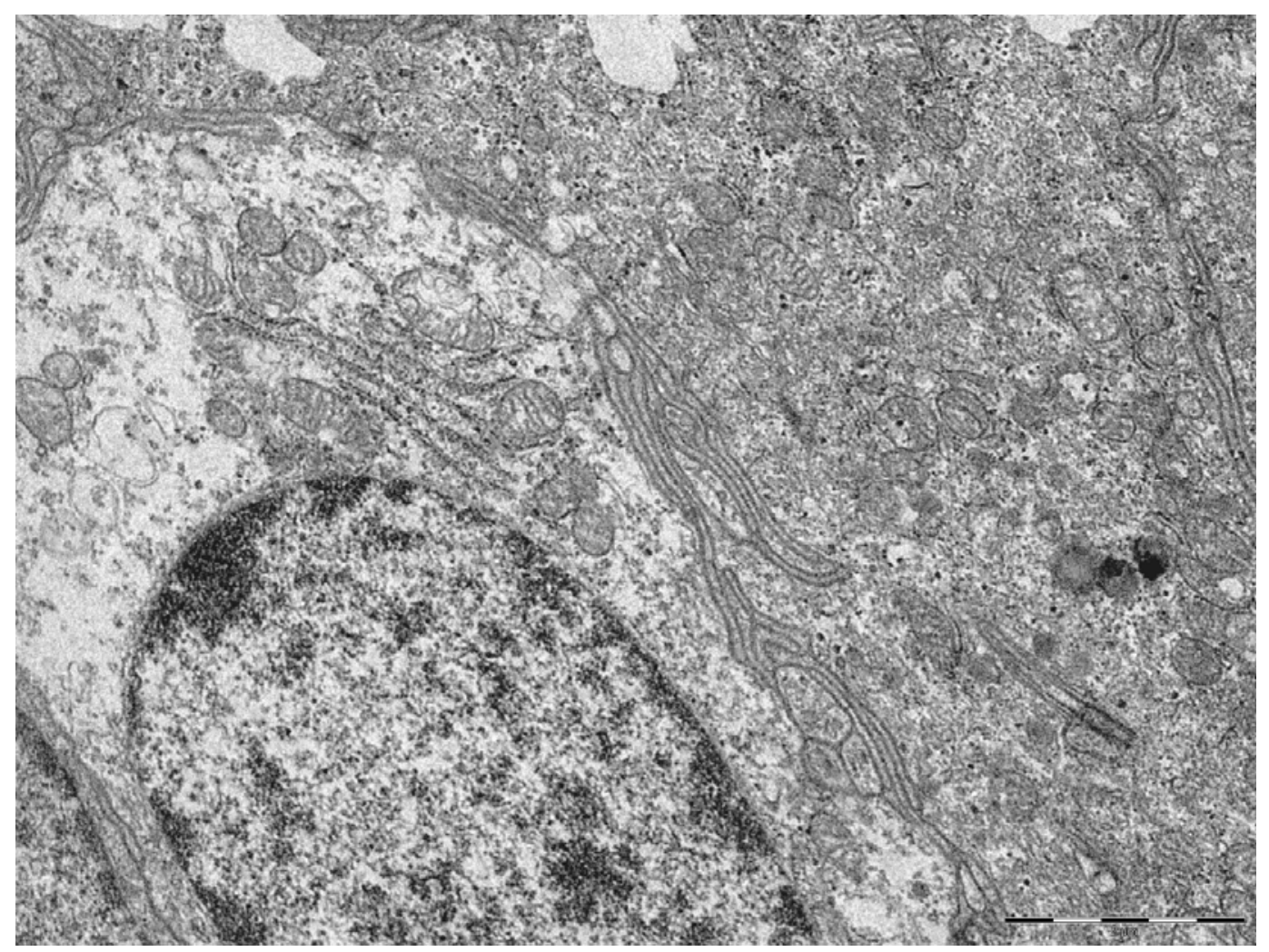

Figura 2 - Micrografia eletrônica de tecido paratireoideo humano, de paciente do grupo prevalente, correspondente ao Tempo 1 (tecido fixado a fresco, sem contato com o meio de transporte). Em destaque uma célula principal com todas as organelas em excelente estado de preservação. Barra $=2 \mu \mathrm{m}$. 


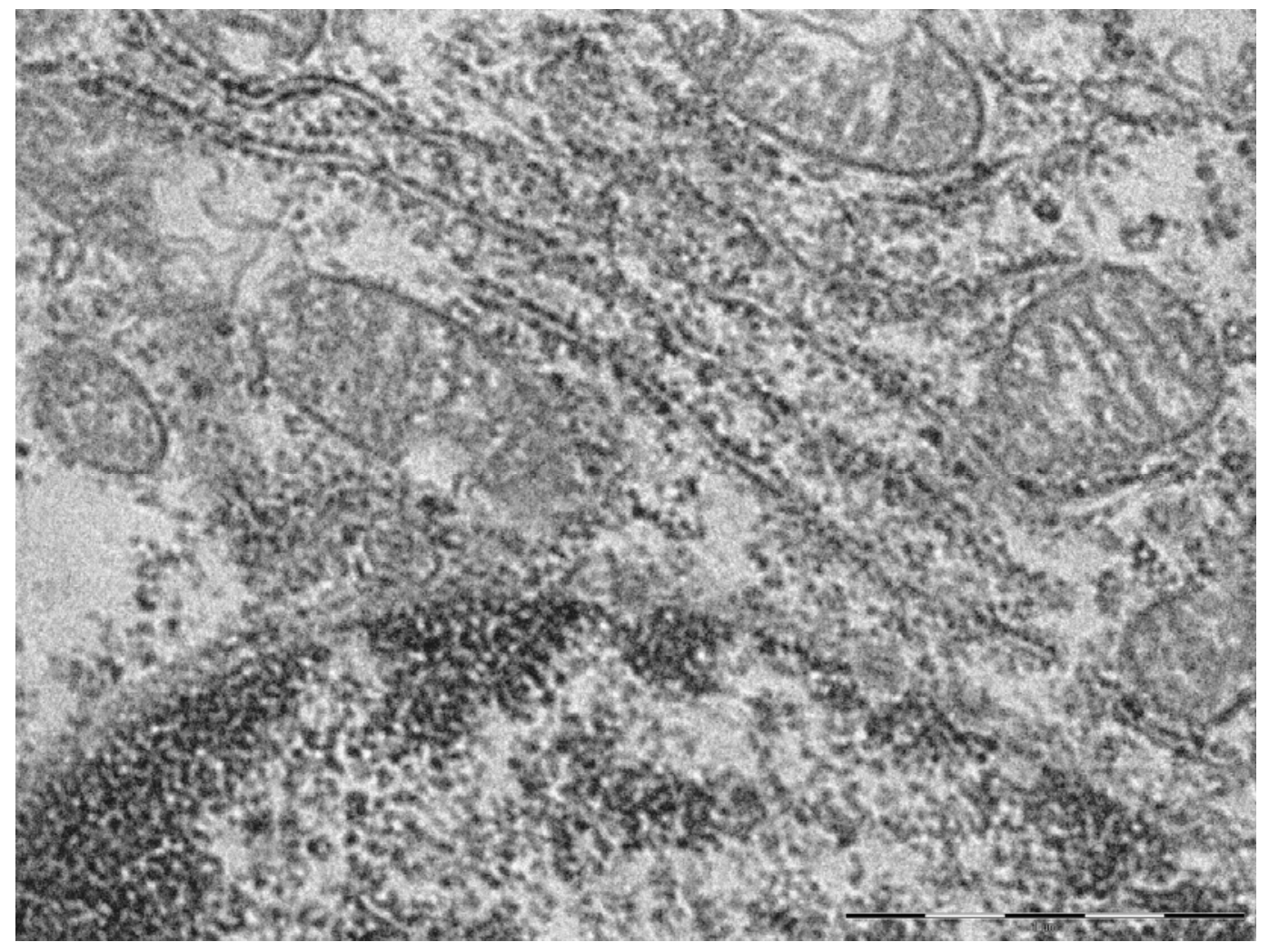

Figura 3 - Micrografia eletrônica de tecido paratireoideo humano, de paciente do grupo prevalente, correspondente ao Tempo 1 (tecido fixado a fresco, sem contato com o meio de transporte. As mitocôndrias apresentam cristas intactas e o retículo endoplasmático rugoso apresentase bem preservado, com sua luz linear e os ribossomos aderidos à sua superfície. Barra $=1 \mu \mathrm{m}$. 


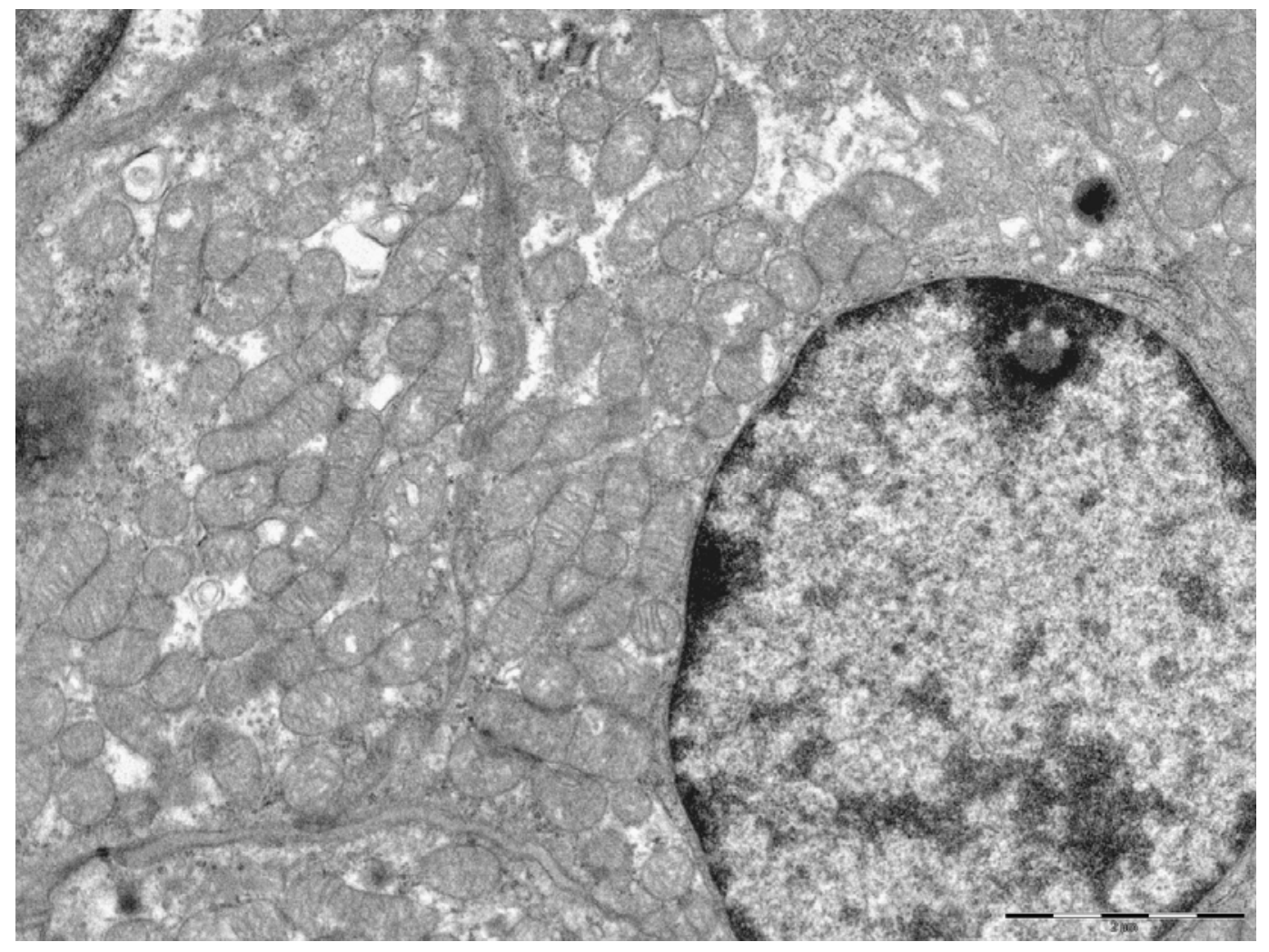

Figura 4 - Micrografia eletrônica de tecido paratireoideo humano, de paciente do grupo prevalente, correspondente ao Tempo 2 (tecido fixado após duas horas em meio de transporte). São visualizadas células oxifílicas, com características normais. Notam-se membranas plasmáticas integras, e com perfeita justaposição. As mitocôndrias apresentam excelente estado de preservação, assim como o núcleo em destaque. Barra $=2 \mu \mathrm{m}$. 


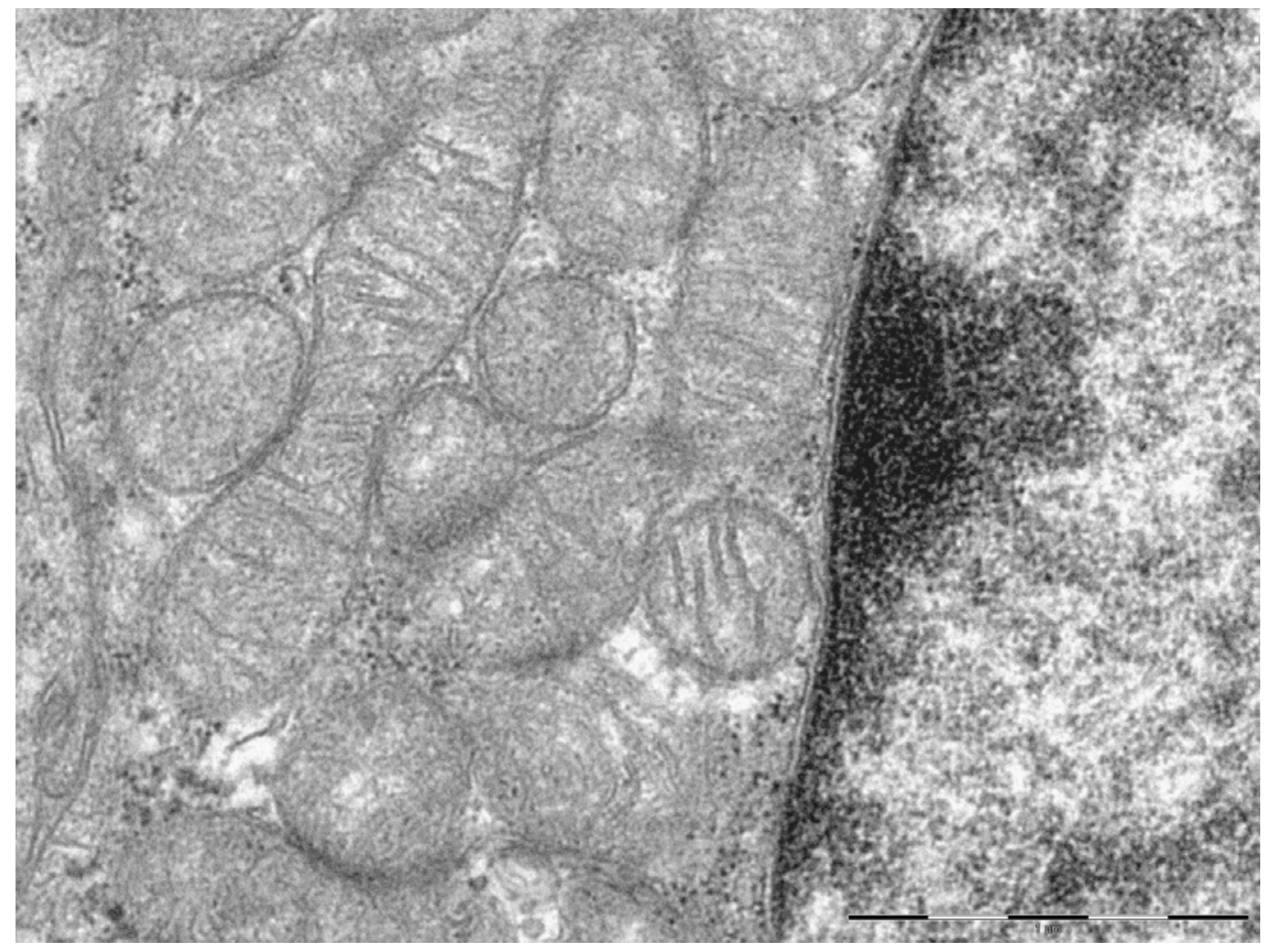

Figura 5 - Micrografia eletrônica de tecido paratireoideo humano, de paciente do grupo prevalente, correspondente ao Tempo 2 (tecido fixado após duas horas em meio de transporte). Em destaque as mitocôndrias apresentam excelente estado de preservação, com formato normal e cristas internas bem definidas. Barra $=1 \mu \mathrm{m}$. 


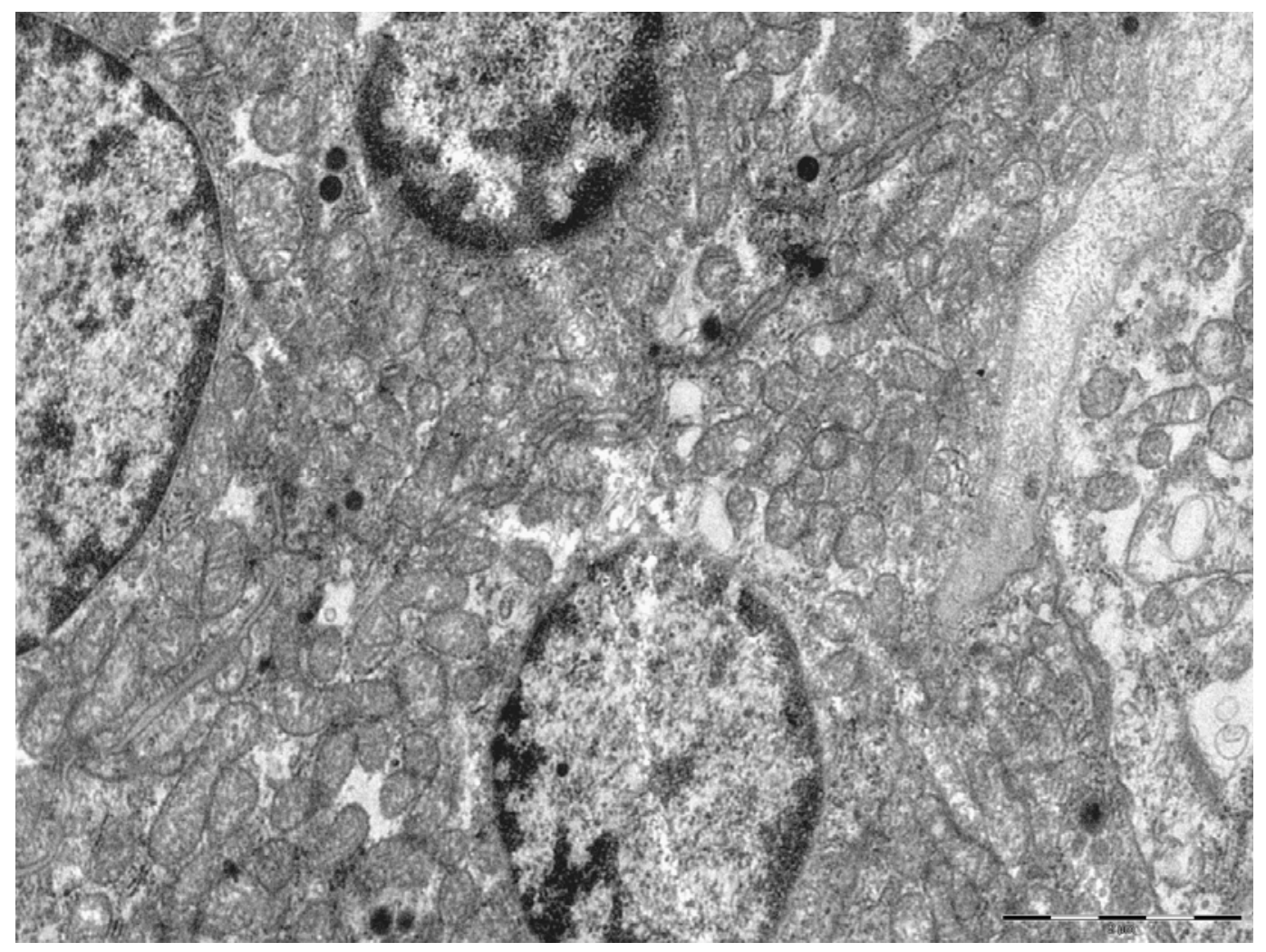

Figura 6 - Micrografia eletrônica de tecido paratireoideo humano, de paciente do grupo prevalente, correspondente ao Tempo 3 (tecido fixado após seis horas em meio de transporte). São visualizadas células oxifílicas, com características normais. Notam-se membranas plasmáticas integras, e com perfeita justaposição. As mitocôndrias apresentam excelente estado de preservação, com cristas bem definidas. Barra = $2 \mu \mathrm{m}$. 


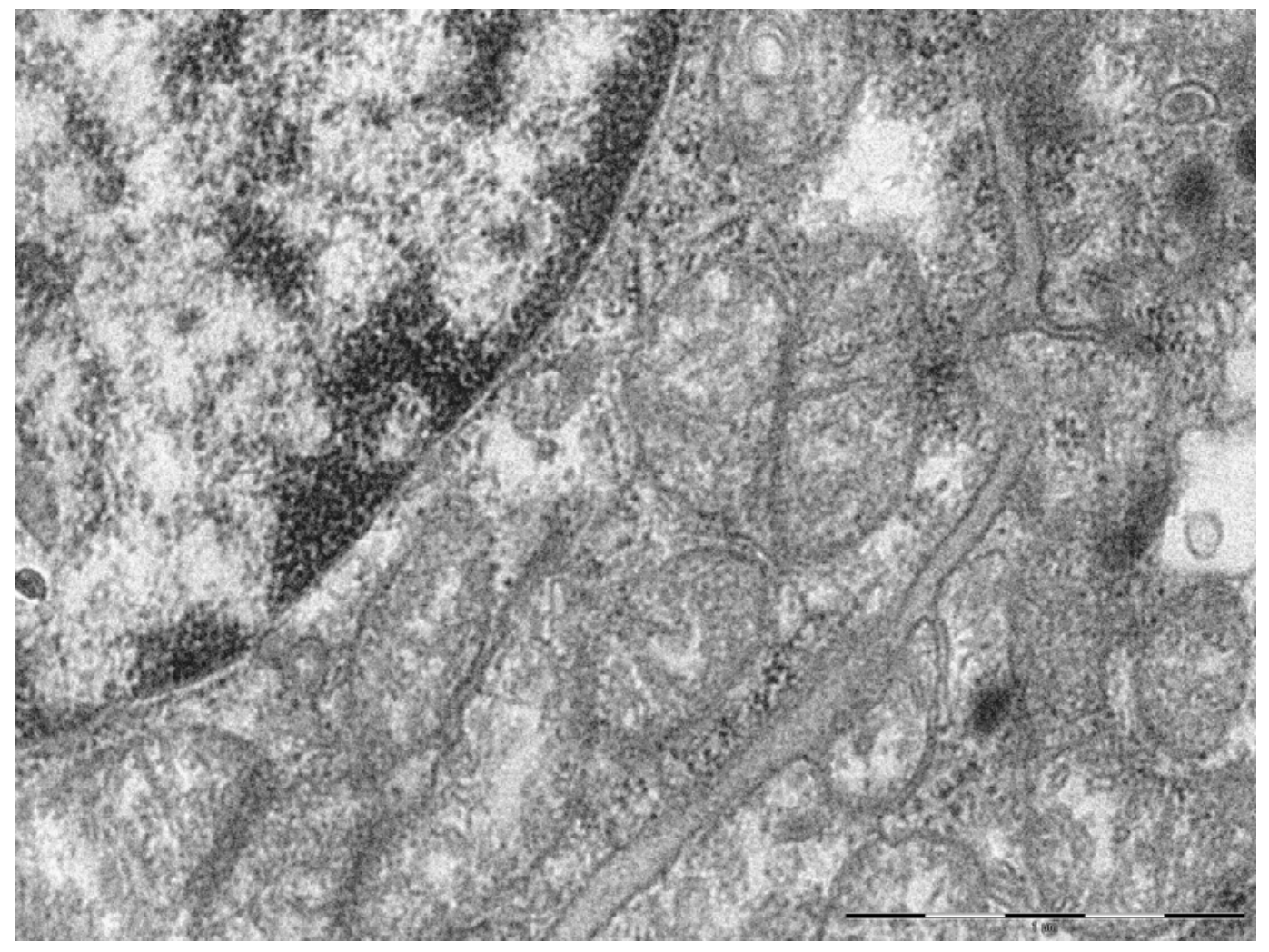

Figura 7 - Micrografia eletrônica de tecido paratireoideo humano, de paciente do grupo prevalente, correspondente ao Tempo 3 (tecido fixado após seis horas em meio de transporte). Neste grande aumento notam-se membranas plasmáticas integras, e com perfeita justaposição. As mitocôndrias apresentam cristas intactas e formato normal. Barra $=1 \mu \mathrm{m}$. 


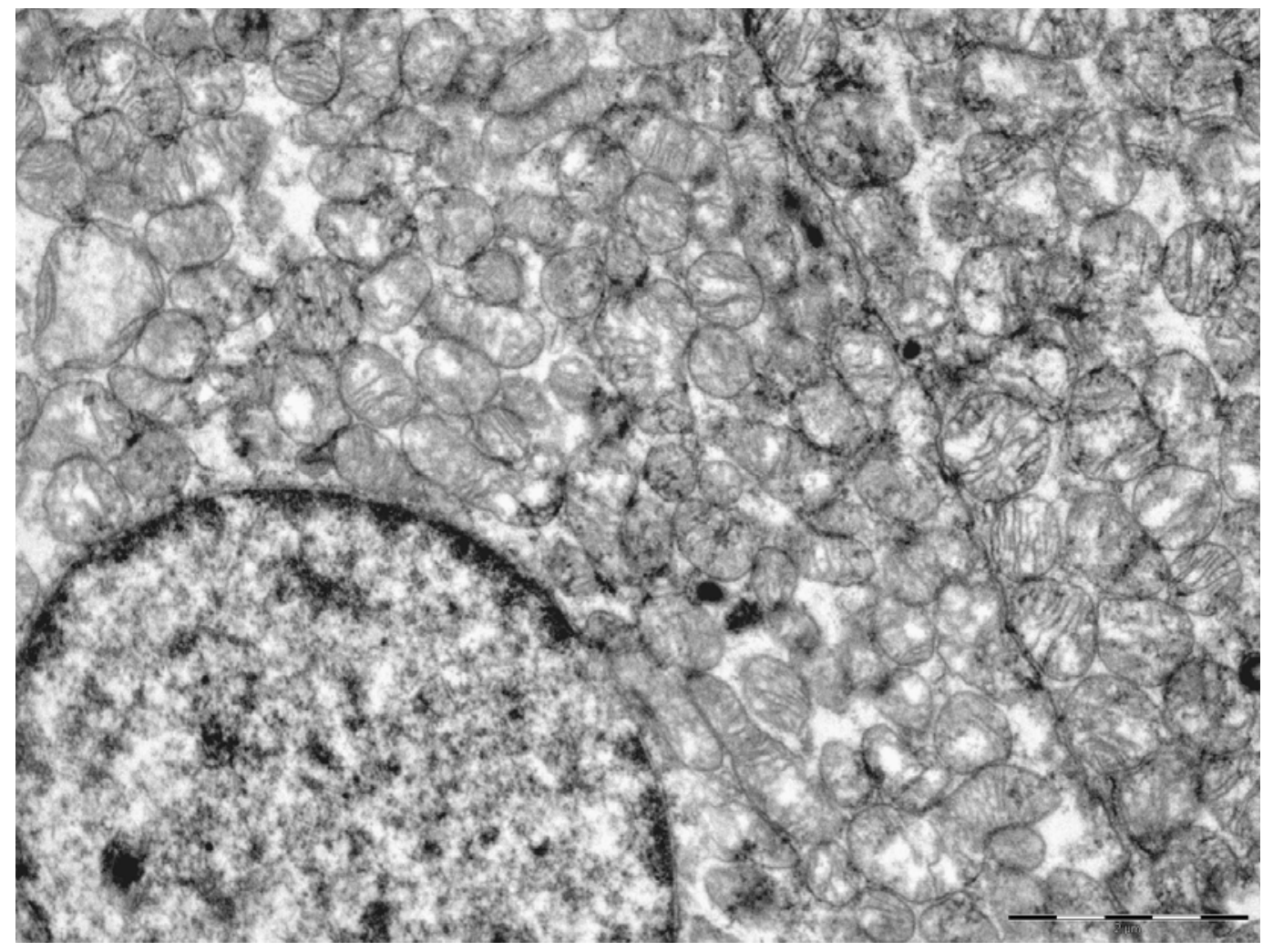

Figura 8 - Micrografia eletrônica de tecido paratireoideo humano, de paciente do grupo prevalente, correspondente ao Tempo 4 (tecido fixado após doze horas em meio de transporte). São visualizadas células oxifílicas, com características normais. Notam-se membranas plasmáticas integras, e com perfeita justaposição. As mitocôndrias apresentam bom estado de preservação. Barra $=2 \mu \mathrm{m}$. 


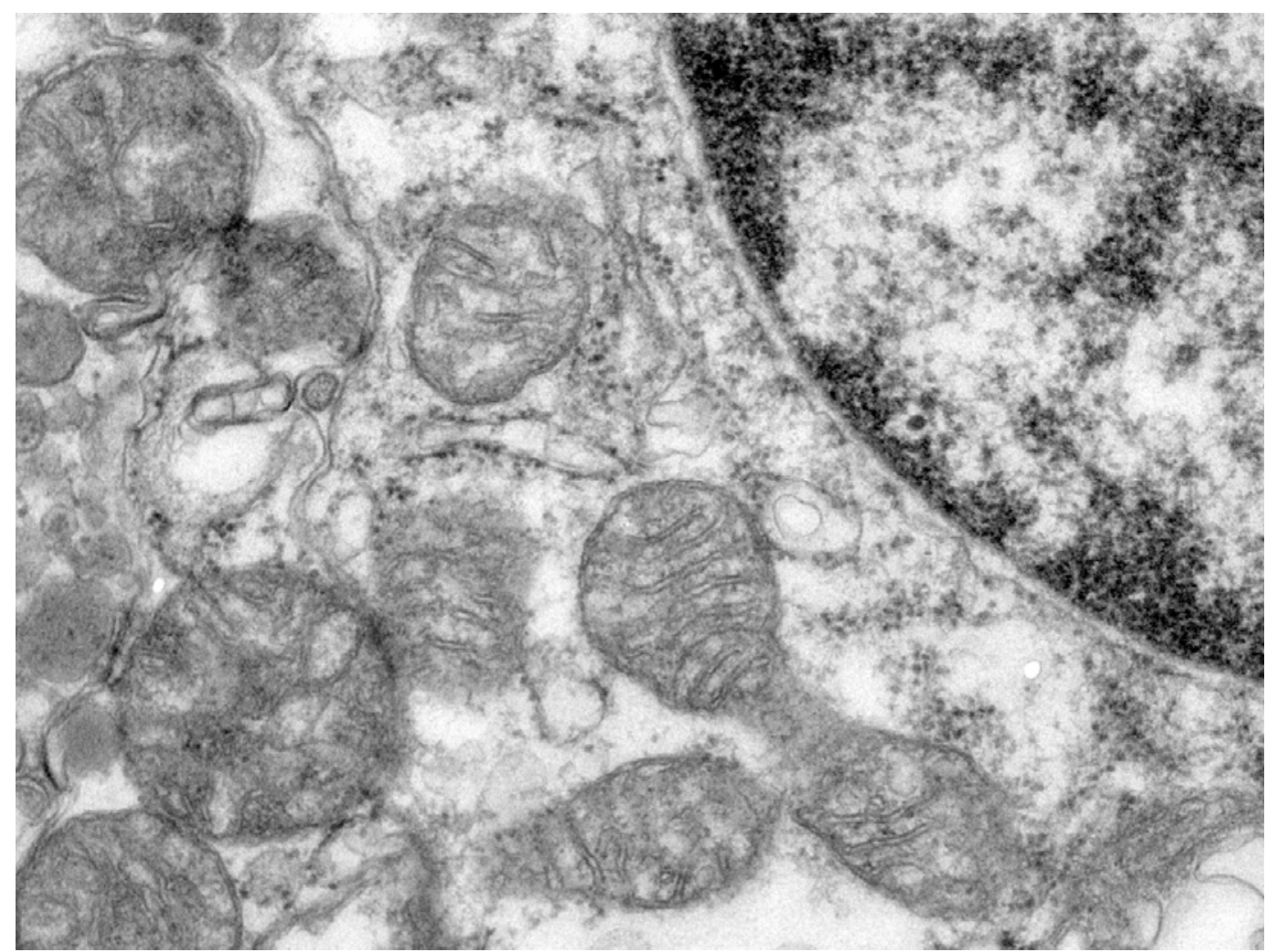

Figura 9 - Micrografia eletrônica de tecido paratireoideo humano, de paciente do grupo prevalente, correspondente ao Tempo 4 (tecido fixado após doze horas em meio de transporte). Em destaque células principal, com características normais. Notam-se mitocôndrias com excelente estado de preservação, e cristas bem definidas. Pode-se observar a integridade do envoltório nuclear com os ribossomos aderidos na sua face citoplasmática.

No tempo 5, todos pacientes deste grupo apresentaram alterações em pelo menos uma das características analisadas neste estudo, e referidas na tabela 6 . As alterações constantes nestes nove pacientes, no tempo 5, foram relacionadas a processo de degeneração geral do citoplasma, inclusive das mitocôndrias. Foram evidenciadas perda da elétron densidade, com degeneração das cristas e formação de vacúolos. Entre estes pacientes, apenas dois apresentaram células com deformidades também na estrutura dos núcleos, e ruptura das membranas plasmáticas, simultaneamente, com configuração de morte 
celular inequívoca. As figuras 10 e 11 exemplificam as alterações mitocondriais, e a figuras 12 , as alterações nucleares, nas membranas plasmáticas e de adesão celular. Estas características ultra-estruturais estão relacionadas com apoptose e morte celular, o que aponta para uma resposta não desejada para preservação do tecido paratireoideo humano, por 24 horas no meio de transporte estudado.

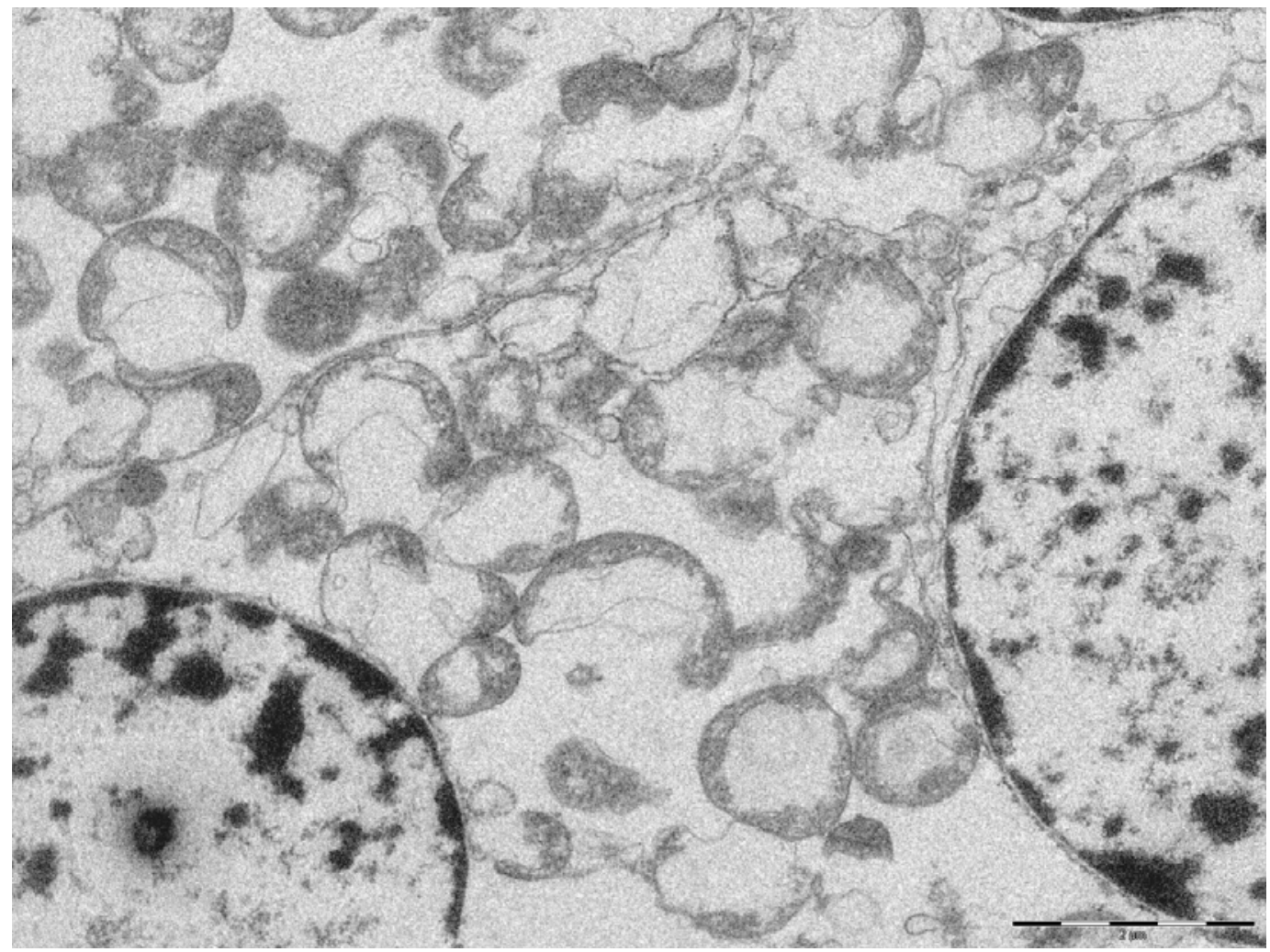

Figura 10 - Micrografia eletrônica de tecido paratireoideo humano, de paciente do grupo prevalente, correspondente ao Tempo 5 (tecido fixado após vinte e quatro horas em meio de transporte). As células apresentamse repletas de vacúolos e não é possível identificar mitocôndrias íntegras. Barra $=2 \mu \mathrm{m}$. 


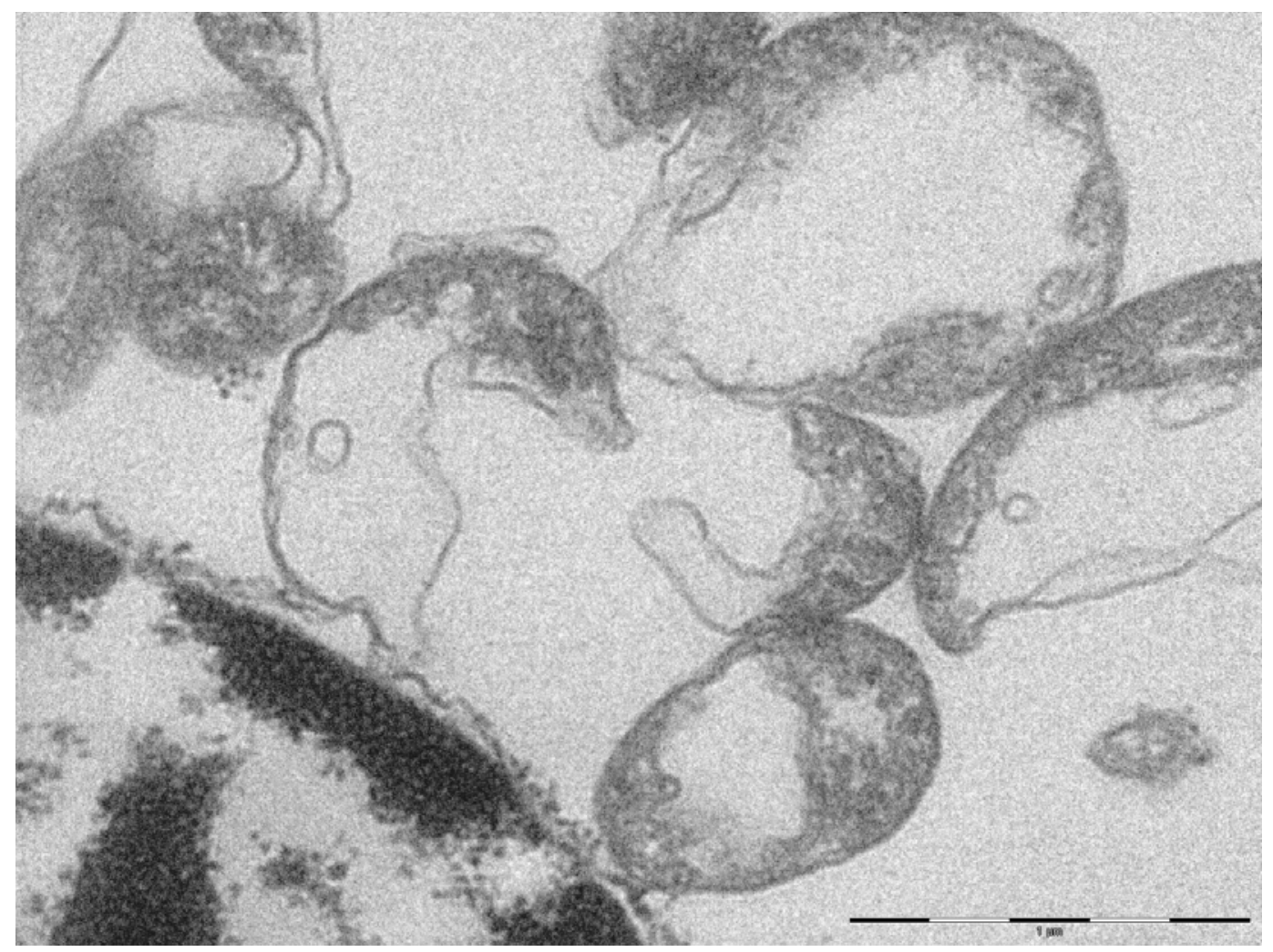

Figura 11 - Micrografia eletrônica de tecido paratireoideo humano, de paciente do grupo prevalente, correspondente ao Tempo 5 (tecido fixado após vinte e quatro horas em meio de transporte) em maior aumento que na Figura 10. Observar sinais de morte celular, com o citosol opticamente vazio e vacúolos em processo de degeneração. Embora o núcleo esteja aparentemente íntegro, a membrana do envoltório nuclear apresenta perfil irregular e sem os ribossomos que lhe são característicos. Barra $=1 \mu \mathrm{m}$. 


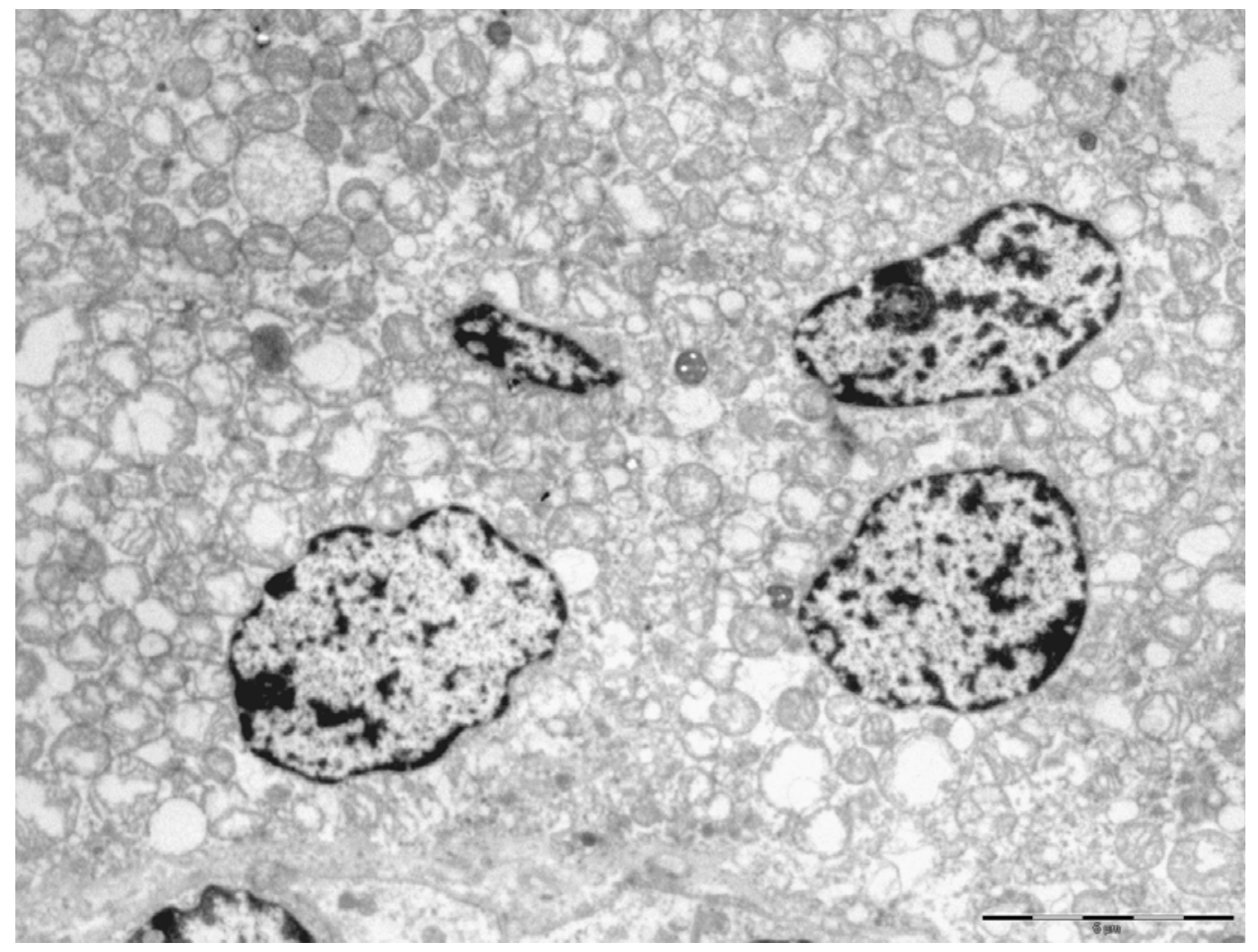

Figura 12 - Micrografia eletrônica de tecido paratireoideo humano, de paciente do grupo prevalente, correspondente ao Tempo 5 (tecido fixado após vinte e quatro horas em meio de transporte). Além da maioria das mitocôndrias apresentarem formações vacuolares e alterações degenerativas, observar que as células não se apresentam mais envolvidas individualmente por membrana plasmática. Barra $=4 \mu \mathrm{m}$.

As células dos outros dois pacientes apresentaram resultados distintos. Uma das amostras cursou com integridade ultra-estrutural em todos os tempos estudados. Sem alterações morfológicas, mesmo após permanência dos fragmentos de paratireóide no meio de transporte por 24 horas. A figura 13 apresenta a análise ultra-estrutural deste paciente no tempo 5, demonstrando preservação das membranas plasmáticas, e adesão celular adequada, além do bom estado morfológico da maioria das mitocôndrias. Nesta figura também nota-se processo degenerativo em 
algumas mitocôndrias, núcleos com formato normal e ausência de edema celular. A presença de desmossomos demonstra boa adesão celular.

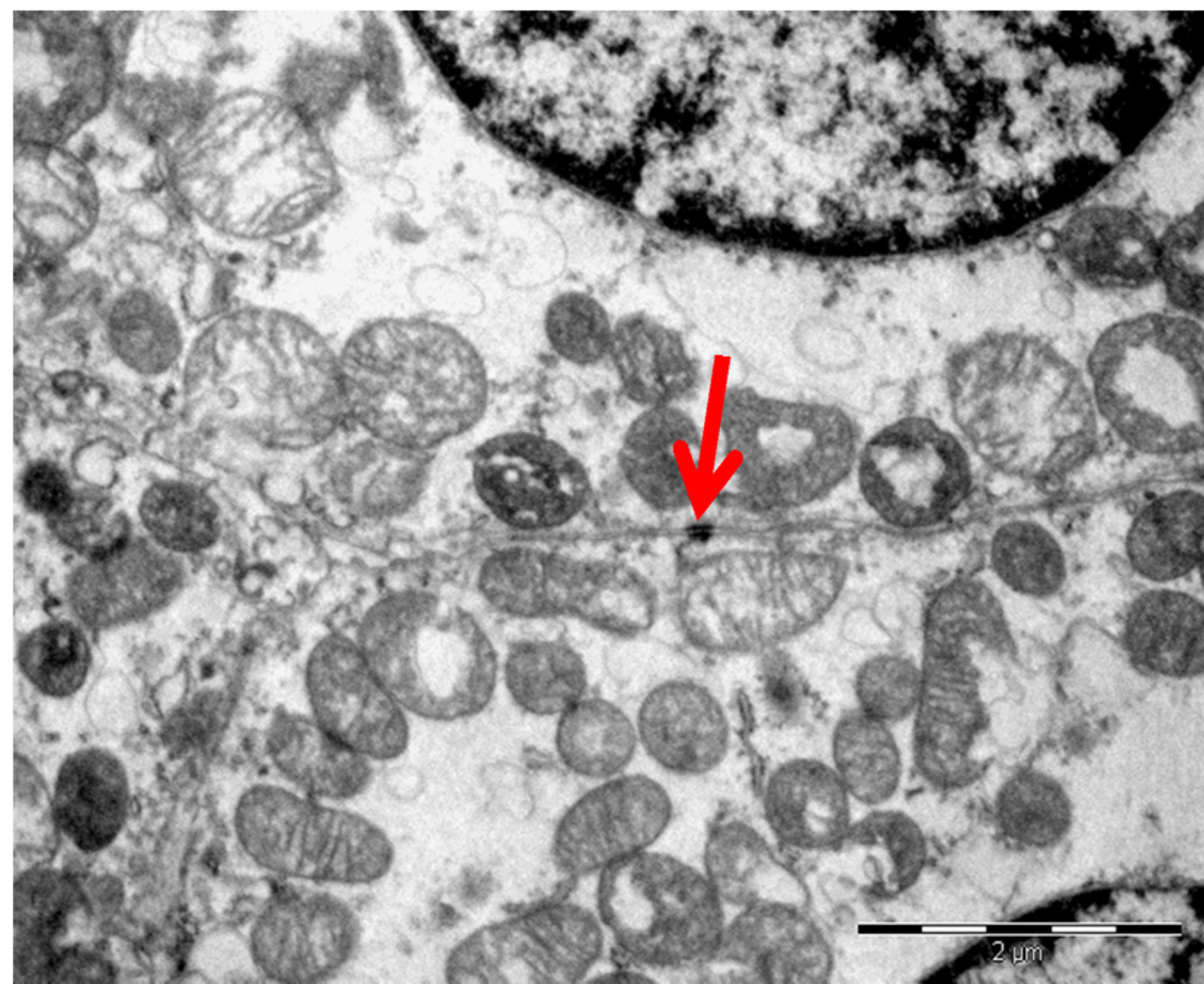

Figura 13 - Micrografia eletrônica de tecido paratireoideo humano, de paciente que apresentou preservação em todos os tempos, correspondente ao Tempo 5 (tecido fixado após vinte e quatro horas em meio de transporte), com aumento de 8.900x. Notam-se ausência de edema, a maioria das mitocôndrias apresenta-se com bom aspecto de preservação e com cristas integras. Algumas poucas mitocôndrias apresentarem formações vacuolares e alterações degenerativas. Também é possível observar a boa condição de adesão celular e preservação das membranas plasmáticas. A seta vermelha aponta para desmossomo. Barra $=2 \mu \mathrm{m}$.

A amostra tecidual do outro paciente apresentou sinais de apoptose e morte celular, desde o tempo 1. Mesmo nos fragmentos de paratireóide fixados a fresco, sem contato com o meio de transporte, a análise ultra-estrutural demonstrou alterações importantes. Foi observado 
edema celular, além da dissolução citoplasmática, e ruptura das membranas celulares, sem possibilidade de distinção dos limites entre as células. As organelas apresentaram-se dispersas e desarranjadas. Também foi observado que a cromatina nuclear encontra-se mais condensada, o que pode ser indicativo de um processo de morte celular já instalado. A figura 14 ilustra as características deste tecido, já com presença de danos celulares no material utilizado como controle (tempo 1), e as figuras 15 e 16 demonstram a evolução da morte celular do tecido deste paciente nos tempos seguintes, com 6 e 24 horas no meio de transporte. Tempos 3 e 5 respectivamente.

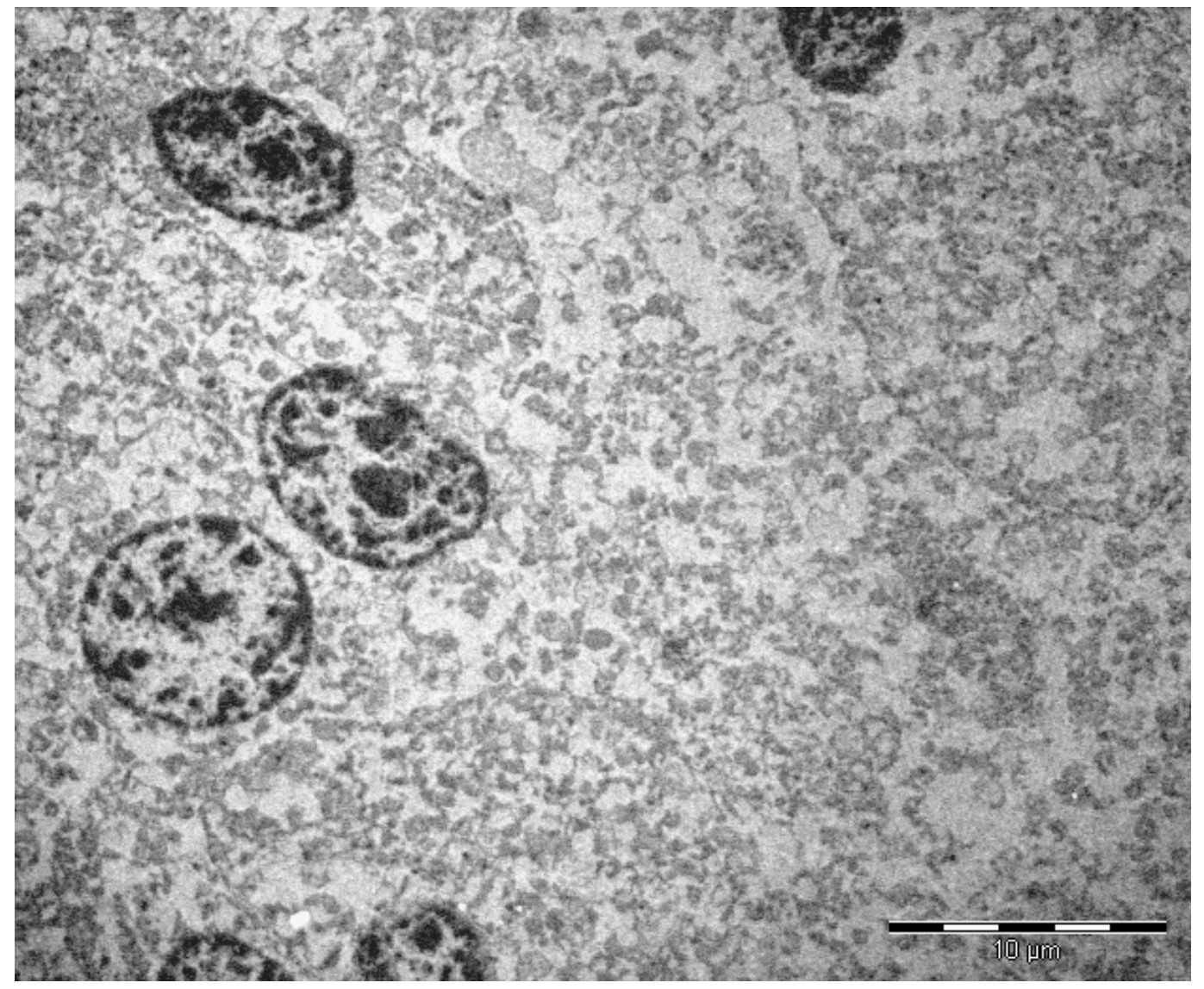

Figura 14 - Micrografia eletrônica de tecido paratireoideo humano, de paciente que apresentou danos celulares em todos os tempos, correspondente ao Tempo 1 (tecido fixado a fresco, sem contato com o meio de transporte). Nesta micrografia de pequeno aumento, as células 
apresentaram ruptura das membranas plasmáticas, com dispersão das organelas. Os núcleos em destaque apresentam condensamento da cromatina e edema nuclear. Barra $=10 \mu \mathrm{m}$.

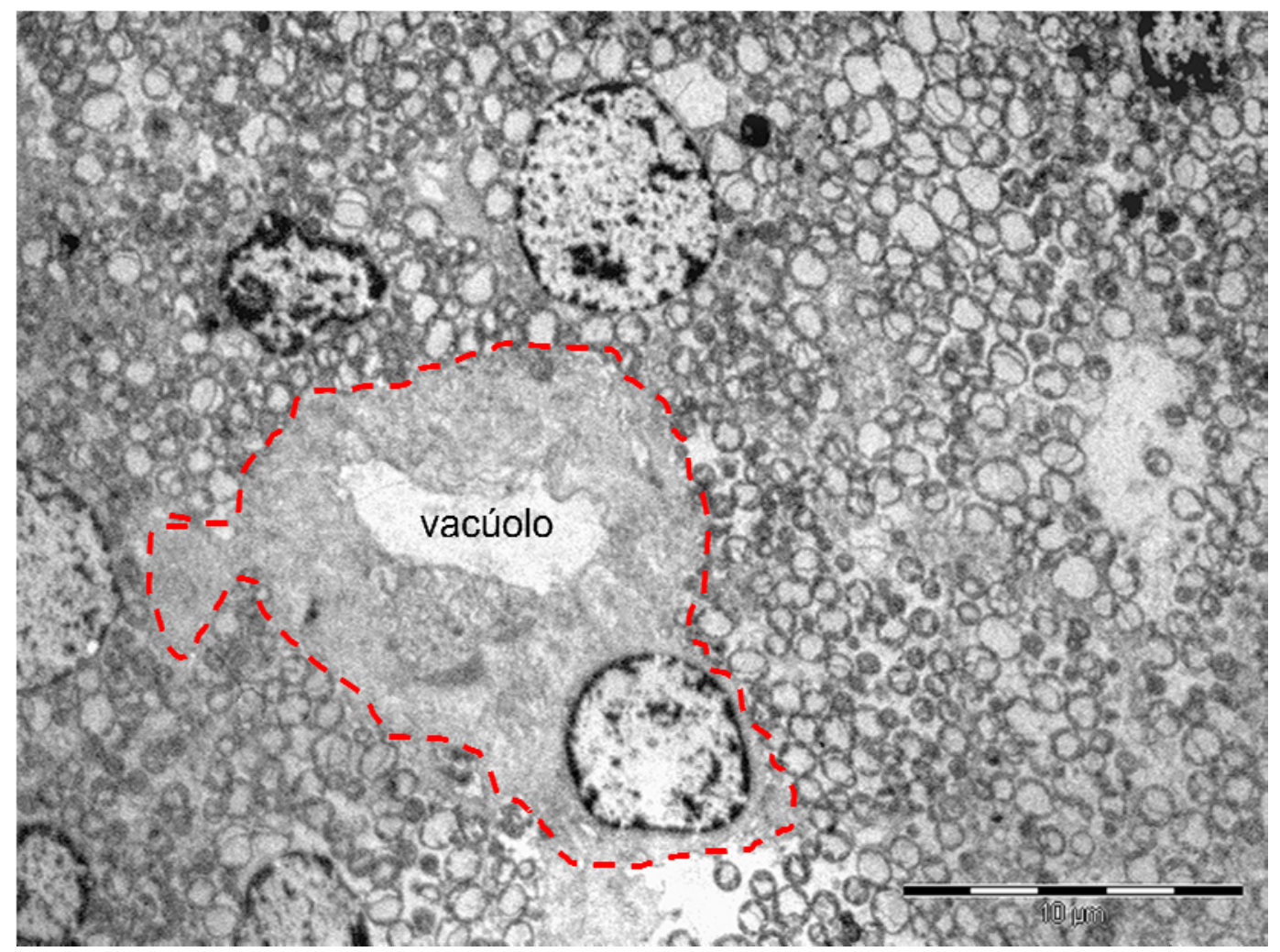

Figura 15 - Micrografia eletrônica de tecido paratireoideo humano, de paciente que apresentou danos celulares em todos os tempos, correspondente ao Tempo 3 (tecido fixado a após imersão em meio de transporte por 6 horas). Além da ruptura das membranas plasmáticas, as mitocôndrias apresentam alterações degenerativas avançadas, com formações vacuolares. Os núcleos em destaque apresentam dissolução da cromatina. Os traços vermelhos envolvem grande formação vacuolar. Barra $=10 \mu \mathrm{m}$. 


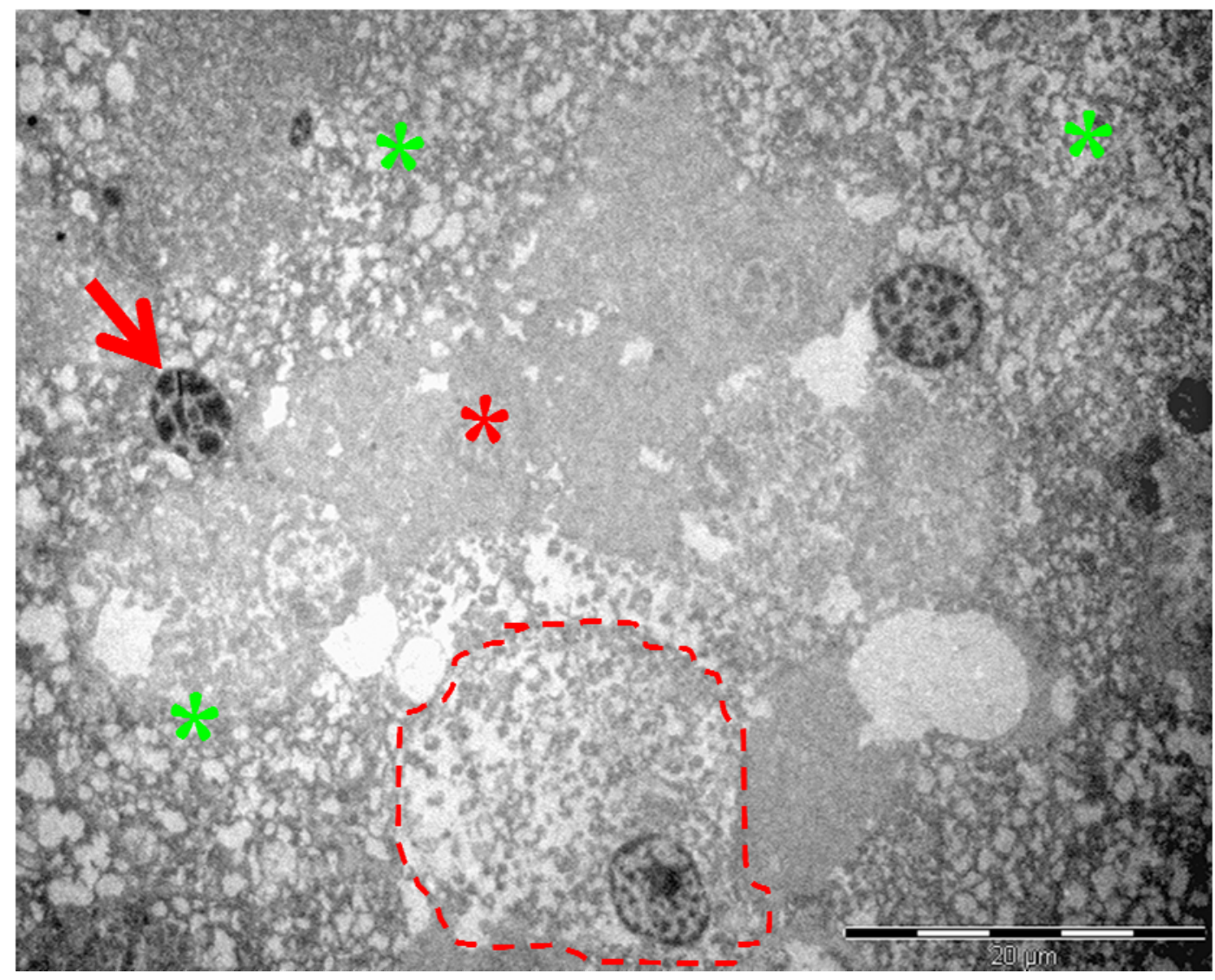

Figura 16 - Fotomicrografia de tecido paratireoideo humano, de paciente que apresentou danos celulares em todos os tempos, correspondente ao Tempo 5 (tecido fixado a após imersão em meio de transporte por 24 horas). As mitocôndrias apresentam alterações degenerativas avançadas. A seta vermelha aponta para aponta para picnose nuclear, o asterisco vermelho marca área de degeneração tecidual, os asteriscos verdes marcam numerosos vacúolos, e os traços vermelhos demarcam célula oxifílica muito edemaciada. Barra $=20 \mu \mathrm{m}$.

No tempo 5 este paciente apresentou definitivamente o aspecto ultraestrutural de morte celular, o tecido apresentou processo de degradação, com sinais de colapso celular, como a picnose nuclear, evidenciada pelos grandes grumos de cromatina condensada na estrutura do núcleo.

A tabela 7 apresenta a caracterização geral dos achados encontrados em cada tempo, em todos os casos. 
Tabela 7 - Caracterização geral dos achados, de acordo com a integridade ou danos teciduais encontrados no tecido avaliado por ME

\begin{tabular}{|llllll|}
\hline caso & tempo 1 & tempo 2 & tempo 3 & tempo 4 & tempo 5 \\
& (controle) & (2 horas) & (6 horas) & (12 horas) & (24 horas) \\
1 & integridade & integridade & integridade & integridade & danos \\
2 & integridade & integridade & integridade & integridade & danos \\
3 & integridade & integridade & integridade & integridade & danos \\
4 & integridade & integridade & integridade & integridade & danos \\
5 & integridade & integridade & integridade & integridade & danos \\
6 & integridade & integridade & integridade & integridade & danos \\
7 & integridade & integridade & integridade & integridade & danos \\
8 & integridade & integridade & integridade & integridade & danos \\
9 & integridade & integridade & integridade & integridade & danos \\
10 & integridade & integridade & integridade & integridade & integridade \\
11 & danos & danos & danos & danos & danos \\
\hline
\end{tabular}


6 DISCUSSÃO 


\subsection{Relevância clínica deste estudo}

A insuficiência renal crônica é um importante problema de saúde pública no Brasil, com estimativas que apontam para mais de 87.000 pacientes em diálise, em todo país ${ }^{12}$. O censo de 2008 da Sociedade Brasileira de Nefrologia, também refere que aproximadamente $25,6 \%$ dos pacientes em diálise, neste período, apresentaram hiperparatireoidismo secundário, com níveis de PTH maiores que $300 \mathrm{pg} / \mathrm{ml}$.

No Brasil, não existem dados referentes ao número de pacientes com hiperparatireoidismo secundário, que necessitam de tratamento cirúrgico. Estima-se que $5 \%$ destes pacientes em diálise, necessitam desta modalidade de tratamento ${ }^{9}$. Em uma estimativa com esses dados, pode-se concluir que mais de 4.000 pacientes com HPT2, podem necessitar de tratamento cirúrgico no Brasil. Estes números podem ser subestimados, já que a Associação Européia de Diálise e Transplante relatou que $15 \%$ dos pacientes em diálise por mais de 10 anos podem necessitar de tratamento cirúrgico ${ }^{10}$.

O tratamento cirúrgico pode ser efetuado por três técnicas diferentes, variando de acordo com a preferência do cirurgião, ou da instituição responsável pelo tratamento do paciente. Tanto a paratireoidectomia total, com ou sem auto-implante, quanto à paratireoidectomia subtotal, cursam com índices variados de complicações e resultados.

Os dados relacionados com as taxas de hipoparatireoidismo persistentes devido à ressecção cirúrgica das paratireóides são relevantes para o presente estudo. Níveis muito baixos ou indetectáveis de PTH são 
relacionados com doença óssea adinâmica, e suas conseqüências a longo prazo, devido a ausência de remodelação óssea ${ }^{14,31,59}$.

Os índices de hipoparatireoidismo variam em diversos trabalhos, Gagné e colaboradores ${ }^{60}$ publicaram artigo em 1992, no qual comparavam a evolução em longo prazo de dois grupos de pacientes. No primeiro grupo, 28 pacientes foram submetidos à paratireoidectomia total com auto-implante e no segundo grupo 21 pacientes, à paratireoidectomia subtotal. Os autores apresentaram uma taxa geral de hipoparatireoidismo de aproximadamente $32 \%$, sem diferença com significado estatístico entre os grupos.

Outros trabalhos demonstram índices menores de hipoparatireoidismo, e descrevem hipofunção do implante em torno de $17 \%{ }^{24,25,26}$. Santos e colaboradores avaliaram 133 pacientes submetidos à paratireoidectomia total com auto-implante, e demonstraram taxa de hipoparatireoidismo em aproximadamente $15 \%$ dos casos, não foi possível relacionar fatores preditivos para a hipofunção do implante ${ }^{26}$.

Os dados que referem índices de hipoparatireoidismo são encontrados em todas as técnicas propostas para o tratamento cirúrgico do hiperparatireoidismo secundário a doença renal crônica. Para tratar os pacientes com esta complicação, a criopreservação de fragmentos de tecido paratireoideo é recomendada em todos os casos, com utilização de qualquer uma das técnicas citadas $^{8,58}$.

De acordo com as Diretrizes Brasileiras de Doença Renal Crônica, publicadas em 2004 pela Sociedade Brasileira de Nefrologia ${ }^{61}$, o 
tratamento cirúrgico para o HPT2, deve seguir a paratireoidectomia total, com auto-implante em antebraço ou pré-esternal, e criopreservação de tecido paratireoideo. Esta recomendação faz com que muitos cirurgiões habilitados hesitem em proceder a paratireoidectomia de doentes renais crônicos alegando não disporem de uma estrutura capaz de realizar criopreservação de tecido paratireoideo. Assim, muitos pacientes são incorretamente condenados a persistirem com o HPT, o que aumenta a chance de mortalidade cardiovascular ${ }^{13}$

Um laboratório de criopreservação demanda cuidados especiais e custo elevado, o que impossibilita a implantação de laboratórios para este fim específico, em todo País.

O presente estudo baseou-se nos aspectos morfológicos ultraestruturais para fornecer informações preliminares sobre a viabilidade de tecido paratireoideo hiperplásico, preservado em meio de transporte. Os dados obtidos apresentam indícios de que o tecido estudado pode ser ressecado e transportado para um local com infra-estrutura adequada para criopreservação, dentro de um limite de 12 horas, sem apresentar alterações ultra-estruturais.

Para um país como o Brasil, com dimensões continentais, e desigualdades econômico-regionais marcantes, este dado pode facilitar o tratamento de pacientes portadores de hiperparatireoidismo secundário em regiões que não tenham estrutura para criopreservação. Ele permite dar bases científicas ao estabelecimento de laboratórios com capacidade 
de criopreservação, que possam servir adequadamente determinadas regiões.

\subsection{Limitações deste estudo}

A análise de apenas 11 casos é uma limitação do estudo. Sem dúvida, um número maior de casos poderia fortalecer a constância das observações e possivelmente definir melhor a freqüência de lesões estruturais em cada tempo definido. O aumento da casuística, entretanto, incorre num aumento significativo de custos, que não necessariamente contribuiriam para responder as questões propostas nesta tese.

O trabalho estudou aspectos da ultra-estrutura da célula da paratireóide mantida em meio de transporte, em hipotermia em diversos períodos após sua retirada. Não há trabalhos semelhantes publicados, e os tempos foram definidos empiricamente, baseados na possibilidade de transporte do tecido entre diferentes regiões do Brasil, e na possibilidade de realizar a criopreservação no dia seguinte à ressecção cirúrgica, por motivo de horário de funcionamento dos laboratórios, ou seja, na realidade prática.

A metodologia empregada permite apenas supor a partir de que momento desde a retirada, o tecido possa ser considerado inadequado para criopreservação. De fato, esta metodologia não pode garantir que a integridade estrutural observada na microscopia eletrônica estará associada à função do tecido após criopreservação, pois o próprio processo de criopreservação não foi avaliado. 
Neste estudo foi utilizado método morfológico para tentativa de avaliar a viabilidade do tecido paratireoideo, mantido em meio de cultura de células, a $4^{\circ} \mathrm{C}$. Apesar de este critério apresentar deficiências, por não avaliar diretamente a funcionalidade do tecido em questão, a utilização do material em vivo para realização de testes funcionais, apresenta questões éticas, que não permitiriam o estudo.

Em uma extensa revisão da literatura sobre transplante de paratireoide, Saxe em $1984^{25}$, citou casos publicados por Jordan e por Lance, que haviam realizado autotransplante de tecido paratireoideo em cães. Ambos observaram a integridade morfológica do implante, porem relataram falta de função hormonal nestes animais. Em um estudo com tecido bovino, McHenry ${ }^{62}$, analisou a viabilidade morfológica de células de paratireóide em suspensão submetidas à criopreservação por períodos de 1 a 52 semanas, através de citometria, e concluiu que apesar de aproximadamente $70 \%$ destas células terem sido consideradas viáveis, houve anormalidade nas respostas ao cálcio e ao PTH nos testes in vitro.

Intuitivamente presume-se que quanto maior o período de isquemia, maior o dano celular. Wells e Christiansen ${ }^{43}$ avaliaram funcionalmente, os efeitos da criopreservação e da falta de suprimento sanguíneo no tecido paratireoideo de ratos. No mesmo estudo, os autores realizaram duas experiências distintas. Na primeira, paratireóides foram obtidas de ratos Fischer, estas paratireóides foram divididas em grupos com tratamentos diferentes. Nos três primeiros grupos, as paratireóides foram colocadas em leito muscular (sem vascularização) em temperatura ambiente por 1, 3 
e 6 horas respectivamente. Nos demais grupos as paratireoides foram preservadas em solução com meio de cultura de Waymouth, a temperatura ambiente por 3, 6, 9 e 12 horas. Ao final dos períodos citados as paratireóides foram implantadas em ratos paratireoidectomizados e hipocalcemicos, e os autores demonstraram taxas altas de sucesso em reverter a hipocalcemia em todos os grupos, com exceção do grupo em que as paratireoides permaneceram no leito muscular por 6 horas. $\mathrm{Na}$ segunda experiência as paratireoides, também de ratos Fischer, foram criopreservadas por 3, 6, 9 e 12 meses, e implantadas após estes períodos em ratos paratireoidectomizados e hipocalcemicos. Os três primeiros grupos estudados cursaram com índices de sucesso no implante superiores a $80 \%$, enquanto no grupo de ratos que receberam as paratireoides criopreservadas por 12 meses, apenas 2 ratos (de um total de 10 animais) obtiveram resposta com normalização da calcemia. Os autores compararam os resultados funcionais com os achados histopatológicos dos implantes, e concluíram que os mesmos foram condizentes, ou seja, os implantes com função preservada apresentaram aspectos morfológicos normais ao exame histopatológico, enquanto os implantes sem função mostraram destruição da arquitetura glandular.

Fígari e colaboradores ${ }^{63}$ analisaram fragmentos de paratireóides de 4 pacientes comparando os achados histológicos com os resultados funcionais in vitro. Os fragmentos permaneceram criopreservados por 6 meses, e a análise morfológica envolveu imunohistoquímica com a técnica TUNNEL, com intenção de avaliar apoptose. Estes autores 
concluíram que o tecido paratireoideo permaneceu com características histológicas e funcionais preservadas após a criopreservação.

Até o momento, o autor desconhece algum trabalho que tenha estudado esses tempos em paratireóides de doentes operados. Assim, apesar desta limitação, o estudo pode sugerir a partir de que tempo não se deve proceder à criopreservação. Criopreservar tecido com alterações celulares sugestivas de dano irreversível é um desperdício de recursos humanos e materiais.

\subsection{Escolha da Microscopia Eletrônica}

Em estudo prévio realizado na instituição concluiu-se que a microscopia óptica era um recurso bastante limitado para predição da funcionalidade do tecido de paratireoide criopreservado ${ }^{32}$. Naquele estudo, quinze pacientes foram incluídos e a função do implante pode ser demonstrada em seis (40\%). A autólise foi achada em dois casos, ambos sem sinal de funcionamento. Porém em 13 pacientes, o tecido implantado era normal à microscopia óptica, mas em sete $(53,8 \%)$ não havia funcionamento mesmo após um ano após a operação e apenas seis $(46,2 \%)$ estavam funcionais ${ }^{32}$.

A morte celular é um processo complexo. A apoptose pode ser iniciada por duas vias principais. A via extrínseca é iniciada por receptores celulares de superfície, que levam a ativação da cascata das caspases, diretamente pela ativação da caspase $8^{64}$. E a via intrínseca mediada pelas mitocôndrias. Durante processos de isquemia e degeneração celular, a microscopia eletrônica revela desestruturação das mitocôndrias, 
com alterações no formato da organela, e fragmentação ou desaparecimento das cristas internas ${ }^{65}$. Vários artigos vinculam estas alterações à liberação do citocromo c pelas mitocôndrias 65, 66, 67, 68 . Quando o citocromo c é liberado no citosol, ocorre ativação dos apoptosomos, que ativam diretamente a caspase 9 , o que leva certamente a morte celular ${ }^{65,69}$. No presente estudo, a análise ultraestrutural das mitocôndrias demonstrou ser a característica mais precoce e constante de apoptose e morte celular.

Um artigo semelhante ao presente estudo avaliou a preservação de córneas humanas em solução para preservação de tecido a $4^{\circ} \mathrm{C}{ }^{70}$. Este artigo comparou os achados morfológicos de apoptose e morte celular, com utilização de microscopia eletrônica de transmissão e com análise imuno-histoquímica para marcador de apoptose. Como reagente para imuno-histoquímica foi utilizado TUNNEL (terminal deoxynucleotidyl transferase biotin-dUTP nick end labeling). $\mathrm{O}$ artigo demonstrou que a microscopia eletrônica de transmissão foi significativamente mais eficiente em caracterizar a apoptose, do que a análise imuno-histoquímica referida.

Elmore, em um extenso artigo de revisão publicado em $2007^{71}$, considerou a microscopia eletrônica de transmissão como método padrão ouro para confirmar apoptose celular. White e Cinti em $2004^{72}$, concluíram que o reconhecimento de células apoptóticas são irrefutáveis, quando características como adesão celular, núcleos elétron-densos, organelas citoplasmáticas, integridade da membrana celular, e formações 
vacuolares poderem ser avaliadas. Estas características foram avaliadas no presente estudo.

\subsection{Discussão dos achados do estudo}

Com os resultados obtidos neste estudo, pode-se sugerir que o tecido paratireoideo pode ser encaminhado para o processo de criopreservação com período de até 12 horas para transporte do tecido. Este dado pode ser considerado, apesar do número de pacientes avaliados, pois todos os fragmentos de tecido paratireoideo (referentes a dez dos onze pacientes) que permaneceram no meio de transporte por até 12 horas, apresentaram integridade ultra-estrutural, tanto celular, quanto tecidual. Entretanto, não podemos assegurar que a integridade da ultra-estrutura corresponde à integridade funcional, quer seja pelo tempo, quer seja pela agressão possível do resfriamento. As realizações de novas pesquisas com estudos funcionais in vitro podem ajudar a esclarecer esta questão.

Álvarez-Hernandez e colaboradores ${ }^{51}$ realizaram recentemente estudos funcionais in vitro, em tecido paratireoideo humano hiperplásico de 18 pacientes. Fragmentos de $1 \mathrm{~mm}$ foram obtidos após paratireoidectomia, e preservados entre 16 a 20 horas em meio de transporte a $4^{\circ} \mathrm{C}$ (o meio de cultura utilizado foi o RPMI), após este período parte dos fragmentos a fresco serviram de controle, parte foi criopreservada por até 18 meses, e outra parte foi cultivada em meio de cultura sem complementos por 60 horas. O estudo avaliou a viabilidade celular por citometria de fluxo, além da resposta do tecido ao cálcio e ao 
calcitriol. A viabilidade celular foi superior a $85 \%$ em todos os grupos, mesmo no tecido cultivado em meio de cultura por 60 horas, que também demonstrou função, em resposta a diferentes concentrações de cálcio. Em apenas $60 \%$ dos casos o tecido a fresco apresentou resposta com aumento da secreção de PTH, em concentrações menores de cálcio. A porcentagem de resposta caiu para $10 \%$ nos casos com tecidos criopreservados. A resposta em relação ao calcitriol foi similar em ambos os grupos, porém apenas $44 \%$ dos casos com tecido a fresco foram responsivos. Este estudo apresentou dados importantes, no entanto as taxas de tecidos responsivos podem ser consideradas baixas, principalmente nos casos dos tecidos estudados a fresco. $\mathrm{O}$ fato dos tecidos terem sido preservados em solução de transporte e hipotermia, por períodos superiores a 16 horas pode ter corroborado com o aumento da incidência dos tecidos não responsivos. Isso talvez possa ser explicado por dano maior em alguns tipos celulares do que em outros, durante o processo de isquemia.

No presente estudo, um dos pacientes cursou com sinais de danos teciduais em todos os tempos avaliados, representando um caso excepcional dentre os outros pacientes do estudo. Neste caso o tecido paratireoideo cursou com sinais de apoptose desde o tempo de controle (fixação a fresco), mesmo antes de o material entrar em contato com o meio de transporte. Alguns fatores podem ter influenciado a evolução desfavorável deste caso. Este paciente foi o único que se submeteu ao tratamento cirúrgico por recidiva do HPT2. Em 1989, o enfermo foi 
submetido à paratireoidectomia, o tratamento foi realizado em outro serviço, e os dados referentes ao procedimento não foram passíveis de resgate. Nesse caso, diferente dos outros, houve um tempo aparentemente maior de isquemia da paratireoide durante a ressecção da glândula. Apesar de recidiva em uma única glândula, esta apresentou dificuldade para dissecção, com muita fibrose e aderência ao nervo laríngeo recorrente relacionado. A glândula em questão teve seus pedículos ligados antes de sua dissecção completa da aderência ao nervo recorrente e exérese definitiva, quando foi coletado material para estudo. Estes dados não podem ser confirmados com exatidão, pois este possível período de isquemia não foi mensurado, referido apenas como impressão pessoal do autor. Podem existir outros fatores relacionados a alterações do próprio tecido, que ainda permanecem desconhecidos. Afinal, a maioria das publicações descreve taxas de sucesso do auto-implante

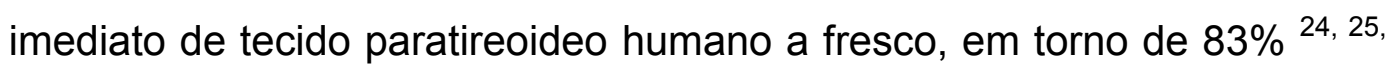
${ }^{26}$, sem respostas claras que expliquem os fatores que determinaram a falta de função do implante. Um fator possível é o leito receptor inadequado, com hematoma e hipoxia tecidual. Entretanto, a observação do presente caso permite questionar se em alguns casos, a simples extração da paratireóide determine dano tecidual irreversível e esse tecido não irá funcionar mesmo no melhor leito possível de implante. Uma analogia pode ser feita às tentativas de autotransplante do córtex da glândula adrenal. Diferente do autotransplante da paratireóide, as tentativas de autotransplante do córtex adrenal são acompanhadas de 
resultados frustrantes nas mais diversas tentativas, talvez por uma grande susceptibilidade do tecido cortical adrenal, com autólise precoce ${ }^{73}$.

Os fragmentos de tecido paratireoideo imersos em meio de transporte por 24 horas, também demonstraram respostas semelhantes em todos os pacientes, com exceção de apenas um caso. Neste período, referente ao tempo 5, em dez casos o tecido apresentou danos ultraestruturais incompatíveis com a manutenção da vida celular. Alterações degenerativas das mitocôndrias foram constantes. As alterações ultraestruturais encontradas em importantes estudos realizados por Roth ${ }^{34}$, Altenähr ${ }^{35}$, e Cinti $^{37}$, e seus respectivos colaboradores, são compatíveis com as alterações encontradas no presente estudo. A abundancia de mitocôndrias, às vezes com formato bizarro, e aumentadas são achados freqüentes em pacientes com HPT2 a doença renal crônica.

Um único caso cursou com integridade celular e tecidual em todos os tempos estudados. O tecido paratireoideo humano permaneceu sem características de apoptose ou morte celular, mesmo após 24 horas de preservação em meio de transporte a $4^{\circ} \mathrm{C}$. Apesar de algumas poucas mitocôndrias já se apresentarem com início de processo de degeneração. Este achado também é de interesse, pois permitiria supor a viabilidade do tecido em casos excepcionais, mesmo após 24 horas da retirada do organismo. A observação deste caso talvez permita contribuir para a análise dos dados de Alvarez-Hernandez, pois é possível supor uma resistência heterogênea do tecido paratireóideo à isquemia. Assim, algumas glândulas teriam uma capacidade maior de resistir mais tempo à 
isquemia. Essa resistência parece existir numa minoria de casos. Uma sugestão de ampliar a casuística e verificar se essa freqüência é maior não é corroborada pelo autor. Os dados do presente estudo sugerem avaliar funcionalmente esses tecidos até 12 horas e não mais pela ultraestrutura.

A criopreservação necessita de cuidados e detalhes minuciosos para execução bem sucedida. Todos os passos devem ser seguidos rigorosamente. É imprescindível que o tecido destinado a este processo esteja em boas condições, com perfeita preservação morfológica e funcional no momento da criopreservação propriamente dita. Os artigos publicados que apresentam os resultados com o implante de fragmentos de paratireóide humana criopreservados, demonstram taxas de sucesso que variam entre 17 a $64 \%{ }^{28,29,30,31}$. Não se sabe ao certo, quais fatores determinam estas baixas taxas de funcionalidade do implante.

O próprio processo de criopreservação parece estar relacionado com danos teciduais. Wagner e colaboradores ${ }^{74}$ sugeriram em artigo publicado em 1986, que a provável causa para a hipofunção dos implantes após a criopreservação poderia estar relacionada a danos teciduais causados por este processo. Os referidos autores identificaram variados graus de autólise (referida como necrose por aqueles autores) nos tecidos criopreservados e reaquecidos a $37^{\circ} \mathrm{C}$, através de análises morfométricas. Posteriormente em 1991, Wagner e colaboradores 31 realizaram estudo com 25 pacientes, e observaram um número de células necróticas entre 0,7 a $52 \%$ nos fragmentos de tecido paratireoideo 
submetidos à criopreservação e reaquecimento, e recomendaram a análise morfométrica antes do implante para avaliar a quantidade de células necróticas, e de acordo com estes dados, implantar mais fragmentos de paratireóide quando a quantidade de células não viáveis no tecido avaliado for significativa.

O período em que os fragmentos de paratireóide permanecem criopreservados também pode influir na viabilidade morfológica e funcional do tecido. Não há consenso sobre este período. Cohen e colaboradores ${ }^{75}$ estudaram 30 casos de implante de tecido paratireoideo e referiram que nenhum dos pacientes que receberam implante criopreservado por mais de 22 meses apresentou função. Guerrero e colaboradores ${ }^{76}$ recentemente estudaram a viabilidade de fragmentos de tecido de paratireóide humana criopreservadas, utilizando hematimetria. Dos 106 espécimes apenas 11 foram considerados viáveis, nenhum fragmento criopreservado por mais de 24 meses foi encontrado com viabilidade. Este estudo de Guerrero chama atenção pelo baixo índice de viabilidade encontrado nos tecidos criopreservados, apenas $10 \%$, isto pode significar problemas na técnica de criopreservação, ou no método de estudo da viabilidade tecidual. Montenegro e colaboradores $^{58}$ relataram dois casos de sucesso no implante de fragmentos de paratireóide humana, criopreservadas por 21 e 30 meses. Neste estudo os dois casos tiveram amostras do tecido após criopreservação e reaquecimento, analisados por microscopia eletrônica, e os achados foram de tecidos considerados viáveis. É possível intuir que deve-se evitar 
que o tecido selecionado para criopreservação seja submetido a danos adicionais durante a preparação e a execução do processo. No presente estudo o caso que apresentou alterações teciduais importantes desde a fixação a fresco, demonstrou que os danos ultra-estruturais podem evoluir rapidamente com autólise, quando o tecido paratireoideo é preservado em meio de transporte a $4^{\circ} \mathrm{C}$.

No presente estudo foi avaliada a fase de preparo e preservação do tecido paratireoideo humano para a criopreservação propriamente dita. O estudo sugere que este tecido selecionado para criopreservação pode ser preservado em solução de transporte a $4^{\circ} \mathrm{C}$, por aproximadamente 12 horas, sem apresentar alterações morfológicas que comprometam a vitalidade do tecido. Este dado pode facilitar a execução do tratamento cirúrgico de pacientes com HPT2, com criopreservação do tecido paratireoideo, em localidades que não possuem laboratórios para este fim específico, se o tempo para transporte do material for menor que 12 horas. Da mesma forma, também não é recomendado que o tecido paratireoideo ressecado permaneça na solução de transporte até o dia seguinte para processo de criopreservação. 
7 CONCLUSÕES 
A análise da ultra-estrutura do tecido da glândula paratireóide hiperplásica de humanos, na solução com meio de cultura de células a 4 graus centigrados, em diversos períodos permite concluir que:

1 - A integridade estrutural da paratireoide humana permanece até cerca de 12 horas após a exérese, na maioria dos casos, mas não em todos.

2 - Houve diferença na avaliação morfológica por microscopia eletrônica (ME) nos diferentes tempos de espera entre si e em relação à paratireoide a fresco na maioria dos casos, mas não em todos.

3 - Na maioria dos casos pode-se conservar o tecido paratireoideo humano no meio de transporte até 12 horas, com manutenção adequada da sua morfologia ultra-estrutural. 
8 REFERÊNCIAS BIBLIOGRÁFICAS 
1 - Cordeiro AC. Contribuição para o estudo da morfologia macroscópica das paratireoides em cirurgia e necropsia [tese livre-docência]. São Paulo: Faculdade de Medicina, Universidade de São Paulo; 1987.

2 - Akerstrom G, Malmaeus J, Bergstrom R. Surgical anatomy of human parathyroid glands. Surgery. 1984;95:14-21.

3 - Numano M, Tominaga $Y$, Uchida $K$. Surgical significance of supernumerary parathyroid glands in renal hyperparathyroidism. World $\mathrm{J}$ Surg. 1998;22:1098-1102.

4 - Bringhurst FR, Demay MB, Kronenberg HM. Hormones and disorders of mineral metabolism. Williams textbook of endocrinology. 9 ed. Philadelphia. WB Saunders. 1998.

5 - Lew Jl, Solorzano CC. Surgical management of primary hyperparathyroidism: state of the art. Surg Clin North Am. 2009;89:120525.

6 - Montenegro FLM, Smith RB, Arap SS, Turcano R, Michaluart Jr. P, Tavares MR, Cernea CR, Brandão LG, Ferraz AR, Cordeiro AC. Ensino de cirurgia das glândulas paratireóides e proposta de índice de estratificação da complexidade das operações. Rev Bras Cir. Cabeça Pescoço. 2008;37: 71-75.

7- Dusso AS, Arcidiacono MV, Sato T, Alvarez-Hernandez D, GonzalezSuarez I, Tominaga Y, Slatopolsky E. Molecular Basis of Parathyroid Hyperplasia. J. of Renal Nutrition. 2007;17:45-7. 
8 - Pitt SC, Sippel RS, Chen H. Secondary and Tertiary Hyperparathyroidism, State of the Art Surgical Management. Surg Clin North Am. 2009;89:1227-39.

9 - Cordeiro AC, Montenegro FLM. Tratado de Cirurgia de Cabeça e Pescoço e Otorrinolaringologia. 1 ed. São Paulo: Atheneu. 2001.

10 - Valderrabano F, Berthoux FC, Jones EH, Mehls O. Report on management of Renal failure in Europe, XXV, 1994 end-stage renal disease and dialysis report. Nephrol Dial Transplant. 1996;11:2-21.

11 - Tominaga $Y$, Matsuoka S, Uno N. Surgical and medical treatment of secondary hyperparathyroidism in patients on continuous dialysis. World $J$ Surg. 2009;33:2335-42.

12 - Censo de Diálise SBN. Disponível em http://www.sbn.org.br/Censo/2008/ censoSBN2008.pdf.

13 - Costa-Hong V, Jorgetti V, Gowdak LHW, Moyses RMA, Krieger EM, Lima JJG. Parathyroidectomy reduces cardiovascular events and mortality in renal hyperparathyroidism. Surgery.2007;142:699-703.

14 - Charhon SA, Berland YF, Olmer MJ, Delawari E, Traeger J, Meunier PJ . Effects of parathyroidectomy on bone formation and mineralization in hemodialyzed patients. Kidney Int. 1985;27:426-35.

15 - Hampl H, Steinmuller T, Frohling P, NaoumC, Leder K, Stabell U, Schnoy N, Jehle PM. Long-term results of total parathyroidectomy without autotransplantation in patients with and without renal failure. Miner Electrolyte Metab 1999; 25: 161-70. 
16 - Stracke S, Keller F, Steinbach G, Henne-Bruns D, Wuerl P. LongTerm Outcome after Total Parathyroidectomy for the Management of Secondary Hyperparathyroidism. Nephron Clin Pract. 2009;111:102-9.

17 - Richards ML, Wormuth J, Bingener J, Sirinek K. Parathyroidectomy in secondary hyperparathyroidism: Is there an optimal operative management? Surgery. 2006;139:174-80.

18 - Patow CA, Norton JA, Brennan MF. Vocal Cord Paralysis and Reoperative Parathyroidectomy. Ann Surg. 1986;203:282-5.

19 - Santos RO. Avaliação de autotransplante intramuscular de tecido paratireoideano na região pré-esternal em pacientes com hiperparatireoidismo secundário e terciário [tese]. São Paulo: Universidade Federal de São Paulo; 2006.

20 -. Arap SS. Hiperparatireoidismo secundário: fatores prognósticos de recidiva atribuída ao implante após paratireoidectomia total e autoimplante [tese]. São Paulo: Universidade de São Paulo; 2005.

21 - Wells SA Jr, Gunnells JC, Shelburne JD, Schneider AB, Sherwood LM. Transplantation of the parathyroid glands in man: clinical indications and results.Surgery. 1975;78:34-44.

22 - Marx SJ: Hyperparathyroid and hypoparathyroid disorders. N Engl J Med. 2000;343:1863-75.

23 - Tominaga Y, Matsuoka S, Sato T. Surgical indications and procedures of parathyroidectomy in patients with chronic kidney disease. Ther Apher Dial. 2005;9:44-7. 
24 - Herrera M, Grant C, van Heerden JA, Fitzpatrick LA. Parathyroid autotransplantation. Arch Surg. 1992;127:825-30.

25 - Saxe A. Parathyroid Transplantation; A review. Surgery 1984;95:50726.

26 - Santos SRC, Luz HLM, Santos GPL, Okada LLS, Ramos DM, Brescia MEG, Lorencetti RRG, Aisawa RK, Montenegro FLM. Fatores preditivos da hipofunção do auto-implante de paratireóide em pacientes submetidos à paratireoidectomia total por hiperparatireoidismo secundário à insuficiência renal crônica. Rev. Bras. Cir. Cabeça Pescoço. 2008;37:20-4.

27 - Wells SA, Gunnells C, Gutman RA, Shelburne JD, Schneider AB, Sherwood LM. The successful transplantation of frozen parathyroid tissue in man. Surgery. 1977;81:86-90.

28 - Rothmund M, Wagner PK. Assessment of parathyroid graft function after auto transplantation of fresh and cryopreserved tissue. World I Surg. 1984;8:527-33.

29 - Herrera M, Grant C, van Heerden JA, Fitzpatrick LA. Parathyroid auto transplantation. Arch Surg. 1992;127:825-30.

30 - Saxe AW, Spiegel AM, Marx SJ, Brennan MF. Deferred parathyroid autografts with cryopreserved tissue after reoperative parathyroid surgery. Arch Surg. 1982;117:538-43.

31 - Wagner PK, Seesko HG, Rothmund M. Replantation of cryopreserved human parathyroid tissue. World J Surg. 1991;15:751-5. 
32 - Montenegro FL, Bento GN, Mello ES, Arap SS, Santa Ritta CE, Reis LM, Graciolli FG, Silva Filho G, Brandão LG, Martin RC, Jorgetti V, Ferraz AR, Cordeiro AC. Aspecto histológico normal à microscopia óptica comum não prognostica o funcionamento do tecido paratiréoideo criopreservado. Rev. Bras. Cir. Cabeça Pescoço. 2008; 37:187-90.

33 - Montenegro FLM. Paratireoidectomia total com ou sem autotransplante no tratamento do hiperparatireoidismo secundário [tese]. São Paulo: Faculdade de Medicina, Universidade de São Paulo; 2000.

34 - Roth SI, Marshall RB. Pathology and ultrastructure of the human parathyroid glands in chronic renal failure. Arch Intern Med. 1969;124:397407.

35 - Altenähr E. Ultrastructural pathology of parathyroid glands. Curr Top Pathol. 1972;56:2-54.

36 - Capen CC. Fine structural alterations of parathyroid glands in response to experimental and spontaneous changes of calcium in extracellular fluids. Am J Med. 1971;50:598-611.

37 - Cinti S, Sbarbati A. Ultrastructure of human parathyroid cells in health and disease. Microsc Res Tech. 1995;32:164-79.

38 - Blumenthal HT, Walsh LB. Survival of guinea pig thyroid and parathyroid autotransplants previously subjected to extremely low temperatures. Proc Soc Exp Biol Med. 1950;73:62.

39 - Lovelock JE, Polge C. The immobilization of spermatozoa by freezing and thawing and the protective action of glycerol. Biochem $\mathrm{J}$. $1954 ; 58: 618-22$. 
40 - Lovelock JE, Bishop MWH. Prevention of freezing damage to living cells by dimethyl sulphoxide. Nature.1959;183:1394-5.

41 - Sonoda T, Ohkawa R, Takeuchi M, Yachiku S. Successful parathyroid preservation: experimental study. Surgery. 1968;64:791-6.

42 - Russell PS, Wood ML, Gittes RF. Preservation of living tissue in the frozen state. A study using parathyroid tissue. J Surg Res. 1961;1:23-31.

43 - Wells SA, Christiansen C. The transplanted parathyroid gland: evaluation of cryopreservation and other environmental factors which affect its function. Surgery. 1974;75:49-55.

44 - Brennan MF, Brown EM, Sears HF, Aurbach GD. Human Parathyroid Cryopreservation:In Vitro Testing of Function by Parathyroid Hormone Release. Ann Surg. 1978;187:87-90.

45 - Brennan MF, Brown EM, Spiegel AM, Marx SJ, Doppman JL, Jones DC, Aurbach GD. Autotransplantation of cryopreserved parathyroid tissue in man. Ann Surg. 1979;189:139-42.

46 - Corominola H, Mendola J, Esmatjes E, Sáenz A, Fernández-Cruz L, Gomis R. Cryopreservation of pancreatic islets prior to transplantation: a comparison between UW solution and RPMI culture medium. Cryobiology. $1998 ; 37: 110-8$

47 - Killinger WA Jr, Dorofi DB, Keagy BA, Johnson G Jr.. Endothelial cell preservation using organ storage solutions. Transplantation. 1992;53:97982.

48 - Disponível em http://en.wikipedia.org/wiki/DMEM. 
49 - Tanaka Y, Funahashi H, Imai T, Wada M, Tominaga Y, Mishra SK, Takagi H. Functional and morphometric study of cryopreserved human parathyroid tissue transplanted into nude mice. World $\mathrm{J}$ Surg. 1996;20:692-9.

50 - Ulrich F, Steinmüller T, Rayes N, Kleespiess A, Grzonka S, Gerlach J, Neuhaus P. Cryopreserved human parathyroid tissue: cell cultures for in vitro testing of function. Transplant Proc. 2001;33:666-7.

51 - Alvarez-Hernández D, González-Suárez I, Carrillo-López N, NavesDíaz M, Anguita-Velasco J, Cannata-Andía JB. Viability and functionality of fresh and Cryopreserved human hyperplastic parathyroid tissue tested in vitro. Am J Nephrol. 2008;28:76-82.

52 - Tsuji K, Fuchinoue S, Kai K, Kawase T, Kitajima K, Sawada T, Nakajima I, Agishi T. Culture of human parathyroid cells for transplantation. Transplant Proc. 1999;31:2697.

53 - Perspectives in cell culture. Managing Serum Requirements for Cell Culture.2001. Disponível em http://tools.invitrogen.com/content/sfs/brochures/ PerspectivesWEB.pdf.

54 - Castleman B, Mallory TB. Parathyroid Hyperplasia in Chronic Renal Insufficiency. Amer J Path. 1937;13:553-74.

55 - Sheldon $\mathrm{H}$, . On the water-clear cell in the human parathyroid gland. J. Ultrastruct. Res. 1964;10:377-83. 
56 - Roth SI. The ultrastructure of primary water-clear cell hyperplasia of the parathyroid glands. Am. J. Path. 1970;61:233-48.

57 - Albright F, Bloomberg E, Castleman B, Churchill ED. Hyperparathyroidism due to diffuse hyperplasia of all parathyroid glands rather than adenoma of one. Arch. Intern. Med. 1934;54:315-29.

58 - Laboratory Stock Solutions and Equipment. Medium formulations. Current Protocols in Cell Biology 2000, Supplt 6.

58 - Montenegro FLM, Custódio MR, Arap SS, Reis LM, Sonohara S, Castro IV, Jorgetti V, Cordeiro AC, Ferraz AR. Successful implant of longterm cryopreserved parathyroid glands after total parathyroidectomy. Head Neck. 2007; 29:296-300.

59 - Motenegro FLM, Custódio MR, Moysés RMA, Reis LM, Jorgetti V, Bradão LG, Cordeiro AC. Paratireoidectomia total sem auto-transplante imediato em hiperparatireoidismo secundário: Jacob Erdheim Revisitado. Rev. Bras. Cir. Cabeça Pescoço. 2009;38:149-52.

60 - Gagné ER, Ureña P, Leite-Silva S, Zingraff J, Chevalier A, Sarfati E, Dubost C, Drüeke TB. Short and long-term efficacy of total parathyroidectomy with immediate autografting compared with subtotal parathyroidectomy in hemodialysis patients. J Am Soc Nephrol. 1992;3:1008-17.

61 - Carvalho AB. Osteodistrofia Renal. J Bras Nefrol. 2004;26:29-39.

62 - McHenry CR, Stenger DB, Calandro NK. The effect of cryopreservation on parathyroid cell viability and function. Am J Surg. $1997 ; 174: 481-4$ 
63 - Fígari M, Lorenti A, Mazzaro E, Plantalech L, Marchitelli H, García M, Argibay P. Resultados iniciales con criopreservación de glándulas paratiroides y potenciales aplicaciones. Rev Argent Cir. 2004;86:111-7.

64 - Suen DF, Norris KL, Youle RJ. Mitochondrial dynamics and apoptosis. Genes Dev. 2008;22:1577-90.

65 - Yamaguchi R, Perkins G. Dynamics of mitochondrial structure during apoptosis and the enigma of Opa1. Biochim Biophys Acta. 2009.1787:963-72.

66 - Chipuk JE, Green DR. How do BCL-2 proteins induce mitochondrial outer

membrane permeabilization? Trends Cell Biol. 2008;18:157-64.

67 - Youle RJ, Strasser A. The BCL-2 protein family: opposing activities that mediate cell death. Nat. Rev. Mol. Cell Biol. 2008;9:47-59.

68 - James DI, Martinou JC. Mitochondrial dynamics and apoptosis: a painful separation. Dev. Cell. 2008;15:341-3.

69 - Bao Q, Shi Y. Apoptosome: A platform for the activation of initiator caspases. Cell Death Differ. 2007;14:56-65.

70 - Komuro A, Hodge DO, Gores GJ, Bourne WM. Cell death during corneal storage at 4 degrees C. Invest Ophthalmol Vis Sci. 1999;40:282732.

71 - Elmore S. Apoptosis: A review of programmed cell death. Toxicol Pathol. 2007;35:495-516.

72 - White MK, Cinti C. A morphologic approach to detect apoptosis based on electron microscopy. Methods Mol Biol. 2004;285:105-11. 
73 - Lucon AM, Mendonça BB, Domenice S, Chambô JL, Wajchemberg BL, Arap S. Adrenal autografts following bilateral adrenalectomy. J Urol. 1993;149:977-9.

74 - Wagner PK, Rumpelt HJ, Krause U, Rothmund M. The effect of cryopreservation on hormone secretion in vitro and morphology of human parathyroid tissue. Surgery. 1986 ;99:257-64.

75 - Cohen MS, Dilley WG, Wells SA Jr, Moley JF, Doherty GM, Sicard GA, Skinner MA, Norton JA, DeBenedetti MK, Lairmore TCLong-term functionality of cryopreserved parathyroid autografts: a 13-year prospective analysis. Surgery. 2005;138:1033-1041.

76 - Guerrero MA, Evans DB, Lee JE, Bao R, Bereket A, Gantela S, Griffin GD, Perrier ND. Viability of cryopreserved parathyroid tissue: when is continued storage versus disposal indicated? World J Surg. 2008;32:8369. 